\title{
ONREL
}

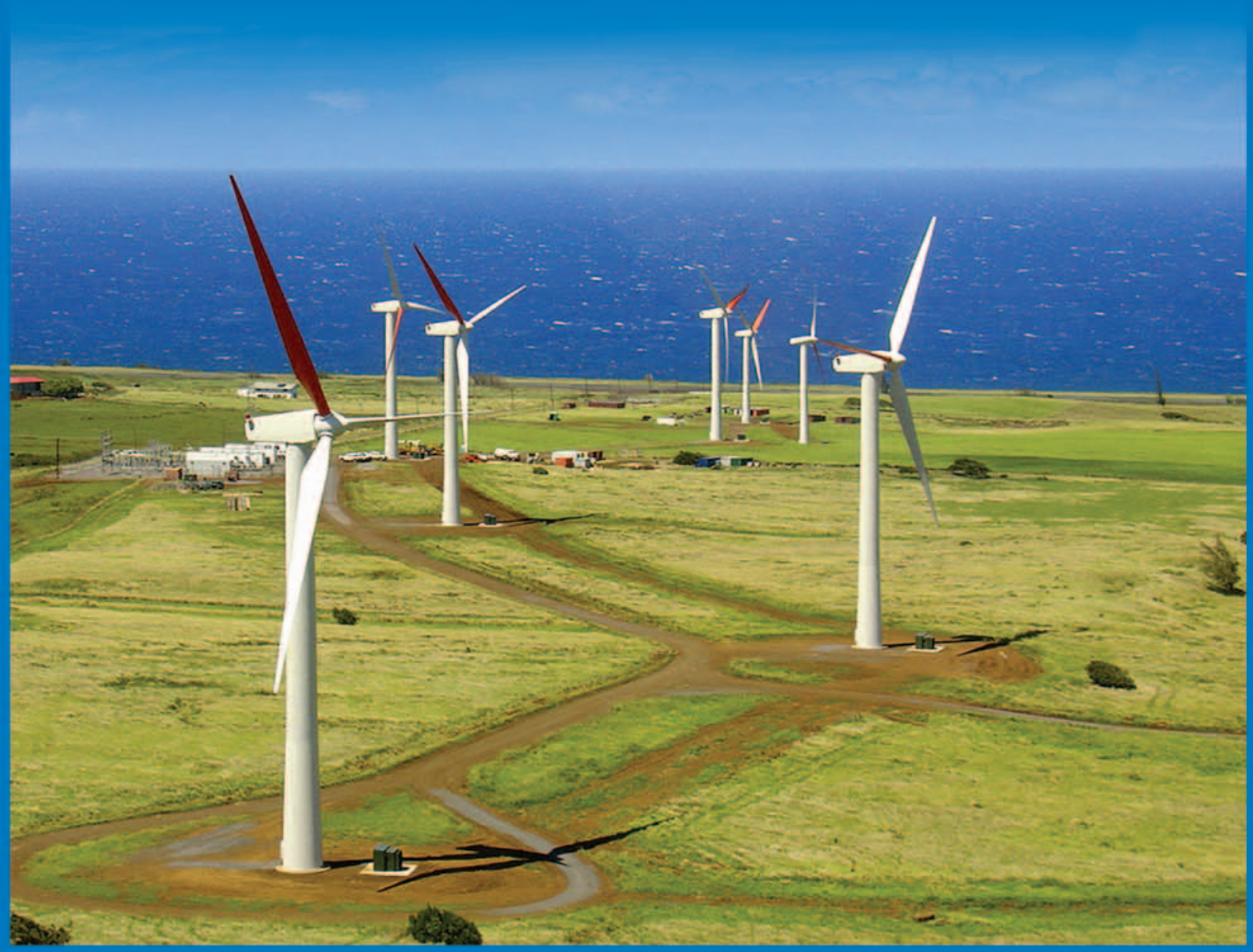

\section{INITIAL ECONOMIC ANALYSIS OF UTILITY-SCALE WIND INTEGRATION IN HAWAII}





\section{NOTICE}

This report was prepared as an account of work sponsored by an agency of the United States government. Neither the United States government nor any agency thereof, nor any of their employees, makes any warranty, express or implied, or assumes any legal liability or responsibility for the accuracy, completeness, or usefulness of any information, apparatus, product, or process disclosed, or represents that its use would not infringe privately owned rights. Reference herein to any specific commercial product, process, or service by trade name, trademark, manufacturer, or otherwise does not necessarily constitute or imply its endorsement, recommendation, or favoring by the United States government or any agency thereof. The views and opinions of authors expressed herein do not necessarily state or reflect those of the United States government or any agency thereof.

Available electronically at $h t t p: / / w w w . o s t i . g o v / b r i d g e$

Available for a processing fee to U.S. Department of Energy

and its contractors, in paper, from:

U.S. Department of Energy

Office of Scientific and Technical Information

P.O. Box 62

Oak Ridge, TN 37831-0062

phone: 865.576 .8401

fax: 865.576 .5728

email: reports@adonis.osti.gov

Available for sale to the public, in paper, from:

U.S. Department of Commerce

National Technical Information Service

5285 Port Royal Road

Springfield, VA 22161

phone: 800.553 .6847

fax: 703.605 .6900

email: orders@ntis.fedworld.gov

online ordering: http://www.ntis.gov/help/ordermethods.aspx

Printed with a renewable-source ink on paper containing at least $50 \%$ wastepaper, including $10 \%$ post consumer waste. 



\section{INITIAL ECONOMIC ANALYSIS OF UTILITY-SCALE WIND INTEGRATION IN HAWAII}

March 2012

Robert Springer

National Renewable Energy Laboratory

NREL/TP-7A40-54248

This report is made possible by funding from the U.S. Department of Energy's Office of Energy Efficiency and Renewable Energy (EERE) Wind Technologies Program and the Office of Electricity (OE) through the Hawaii Clean Energy Initiative (HCEI). A special thanks and acknowledgment goes to Patrick Finch and Ralph Braccio of Booz, Allen, Hamilton for their insight and collaboration on the economic analysis herein (NREL Subcontract No. LGL-0-40279-01). The author thanks Steve Lindenberg (EERE); William Parks (OE); Mary Werner, Ken Kelly, Nancy Carlisle, and John Barnett (NREL); Robbie Alm and Leon Roose (Hawaiian Energy Company); and Estrella Seese, Maria Tome, Allen Kam, and Joshua Strickler (State of Hawaii Department of Business, Economic Development and Tourism) for comments on drafts throughout the process. The author also thanks Devin Egan (NREL) for timely and accurate technical and style edits and layout. Of course, any remaining errors or omissions are the responsibility of the author. 


\section{ACRONYMS \& ABBREVIATIONS}

\begin{tabular}{|c|c|}
\hline CAPEX & capital expenditure \\
\hline CSP & concentrating solar power \\
\hline DBEDT & $\begin{array}{l}\text { Hawaii Department of Business, Economic } \\
\text { Development, and Tourism }\end{array}$ \\
\hline DOE & Department of Energy \\
\hline HCEI & Hawaii Clean Energy Initiative \\
\hline HECO & Hawaiian Electric Company \\
\hline HVDC & high-voltage direct current \\
\hline KW & kilowatt \\
\hline LCOE & levelized cost of energy \\
\hline MECO & Maui Electric Company \\
\hline MSW & municipal solid waste \\
\hline MW & megawatt \\
\hline MWh & megawatt hour \\
\hline NPV & net present value \\
\hline O\&M & operations and maintenance \\
\hline OWITS & Oahu Wind Integration and Transmission Study \\
\hline PUC & Public Utilities Commission \\
\hline PV & photovoltaic \\
\hline RPS & renewable portfolio standard \\
\hline SAM & System Advisory Model \\
\hline SROPTTC & $\begin{array}{l}\text { Site, Resource, Off-take, Permits, Technology, } \\
\text { Team, Capital }\end{array}$ \\
\hline TRC & Technical Review Committee \\
\hline
\end{tabular}




\section{TABLE OF CONTENTS}

Acknowledgements $\ldots \ldots \ldots \ldots \ldots \ldots \ldots \ldots \ldots \ldots \ldots \ldots \ldots \ldots \ldots$

Executive Summary....................................... 4

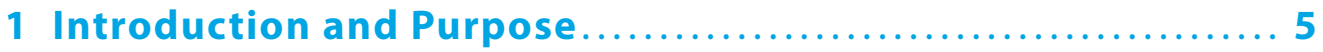

2 Project Background and Context ........................ 7

3 Approach and Methodology............................ 8

4 Big Wind Project Definition ............................. 12

5 Project Alternatives ................................. 14

6 Big Wind Economic Model............................. 18

7 Economic Analysis of Alternatives .................... 21

8 Sensitivity Analysis and Results ....................... 24

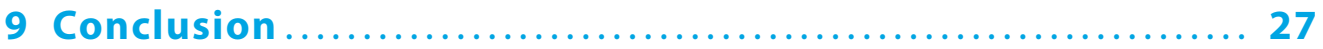

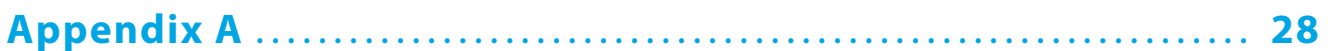

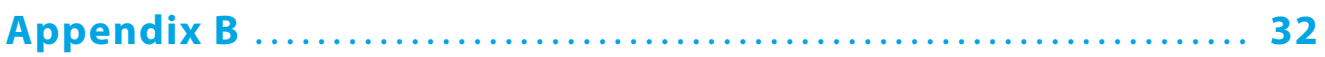

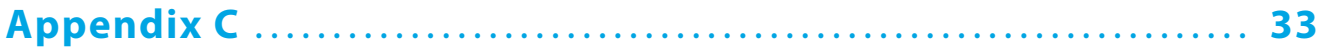




\section{EXECUTIVE SUMMARY}

Hawaii has a variety of renewable energy and energy efficiency resources. This report summarizes an analysis, conducted by the National Renewable Energy Laboratory (NREL) in May 2010, of the economic characteristics of a particular utility-scale wind configuration project that has been referred to as the "Big Wind" project. The project was defined in May 2010 as 400 megawatts (MW) of wind power on the islands of Lanai and Molokai, as well as the necessary undersea cable transmission infrastructure and Oahu grid improvements to utilize the electricity on Oahu, Molokai, and Lanai.

The study was designed to characterize the economics of the project and gain a perspective of its feasibility, given available technical and cost information. The primary question we sought to answer was:

\section{How much revenue would such a project likely \\ require to be successful, and how does that cost relate to the relative energy economics in Hawaii?}

As an early-stage screening analysis, this study does not include enough detail, and is not definitive enough to support a "Go/No Go" decision for such a project to be constructed, and should not be used in that way. The work is meant to inform a "Go Forward/Stop" decision, which either supports or rejects the choice to make incremental investments in the project (Go Forward), or to abandon the effort in preference for an alternative (Stop). In addition, through sensitivity analysis, we seek to understand what incremental investments should be made.

Alternatives to a project must also be considered when making investment decisions. With the objective of compliance with Hawaii's renewable portfolio standard (RPS) as a constraint, none of the alternatives included in this study were shown to have a clear economic advantage to be pursued as replacements to Big Wind. However, many complementary renewable technologies, particularly solar power, are essential to pursue concurrently with Big Wind to achieve the RPS goals. Biofuels, while technically a replacement for Big Wind, was not shown to have a clear enough economic advantage to abandon Big Wind but would very likely be deployed as a complementary resource to Big Wind. Other alternatives, such as geothermal and utility-scale wind on Maui may be economically viable, but were not included at the time of this study.

Our analysis indicates the first year cost (or revenue, from the project's perspective) of power delivered to the grid on Oahu would need be in a range of $\$ 170-\$ 230 /$ megawatt hour (MWh). This corresponds to an expected levelized cost of energy of \$220/MWh, with a range of $\$ 187-\$ 253 / \mathrm{MWh}$. 


\section{Based on this analysis of the project and \\ the alternatives available at this time, the project merits \\ continued investment and further development.}

Based on sensitivity analysis of the input variables to the economic model, it is our recommendation that incremental investments be directed toward the following areas:

1. A more detailed understanding of the power production capability of the wind resource (capacity factor), as integrated into the Oahu grid.

2. A more detailed understanding of the capital costs of the three main areas of investment required: wind farms, cable transmission system, and Oahu grid improvements.

3. A more detailed and robust analysis of execution structures and the corresponding cost of capital for the project, a key driver of project economics.

\section{INTRODUCTION AND PURPOSE}

This report summarizes an analysis of the economic characteristics of a particular utility-scale wind configuration project that has been referred to as the "Big Wind" project. It is intended to contribute to a broader set of analyses that provide objective technical and economic information to help guide and inform decisions related to meeting Hawaii's RPS goals. Other relevant efforts included, but are not limited to, the HCEI Scenario Analyses, Biofuels Master Plan, Oahu Wind Integration studies, Geothermal Working Group report, Hawaii Solar Integration Study, and others.

This specific analysis provides one such evaluation of the economic merits of the Big Wind project in Hawaii given technical merits established by the Oahu Wind Integration Study ${ }^{3}$ in early 2010. OWITS was an in-depth study initiated in 2008 and 2009 to investigate the project's technical aspects. In April 2010, it was concluded from the work done within OWITS that the project was technically feasible; a key milestone in the development of the project.

The study was initiated to assess the financial implications of new information generated from OWITS, and to represent that information in economic terms. The purpose is to provide a basis upon which project stakeholders can consider, understand, and debate the economic feasibility of the Big Wind project, and inform any incremental investments that may be indicated.

This analysis is not a comprehensive financial study. It is a first-level economic screening analysis with the purpose of determining if the project warrants further investment, and if so, with what purpose. We sought to support an incremental decision—“Go Forward/ Stop" where Go Forward means continue to invest and Stop means abandon the project in favor of another alternative. 
Eventually, the project will reach a milestone where a decision that is commonly referred to as a "Go/No Go" decision must be made, where it is determined to fully execute the project or not. The two wind projects referenced in this study have not progressed to the point of a Go/No Go decision. The results of this analysis should not be used or interpreted as supporting a Go/No Go decision, which will only be decided once a more fully developed understanding of the costs, impacts, risks, and benefits of the project can be considered along with the input of the communities involved and other appropriate stakeholders and decision makers.

\author{
In simple terms, we are not seeking to \\ act as the single source to inform the \$2 billion \\ decision of building the project.
}

\title{
1.1 Assumptions, Constraints, and Limitations
}

Several points of reference provide the context for this study, and are important when considering the approach and conclusions made herein.

1. The study was conducted from the perspective of the project economics as a whole, irrespective of the roles and interests of specific parties, including project developers, the utility, or others.

2. Though it is expected that different portions of the project may be executed separately, for example the cable and wind projects, we combine them as a simplifying assumption.

3. The Energy Agreement ${ }^{1}$ and ensuing state renewable portfolio standard (RPS) ${ }^{2}$ were considered as constraints, not intended to be debated as part of this study. Therefore the use of fossil fuels was not considered an alternative, though the economics of the utility's existing energy sources can be, and is, used as a comparison to put costs in perspective.

4. In terms of the broader RPS constraint, we relied upon the high-level analysis and content of the Hawaii Clean Energy Initiative Scenario Analysis ${ }^{4}$. Recognizing the limitations and original purpose of this analysis, it is used here in the absence of any other comprehensive, forward-looking study.

5. This study does not intend to imply any decisions have been made regarding the many issues surrounding the project, including, but not limited to, community acceptance, specific designs, cable routing, cultural impacts, or environmental concerns.

6. This study is intended to inform the decision whether to commit the resources of the community to consider details more fully as the project moves through legislative, regulatory, permitting, and community approvals. 
7. This study was largely conducted prior to the conclusion of and publication of the results of the Oahu Wind Integration and Transmission Study (OWITS). The numbers used in the analysis therefore may vary somewhat from published values.

8. The Big Wind project configuration, and other necessary assumptions made in the analysis, are not an opinion of preference or meant to be prescriptive in any way. Assumptions were made in an effort to make a reasonable estimate of the economics of the project to inform early-stage decision making regarding continued and incremental investment in the project.

\section{PROJECT BACKGROUND AND CONTEXT}

In January 2008, DOE and the Governor of the State of Hawaii signed a memorandum of understanding launching the Hawaii Clean Energy Initiative (HCEI) to transform the energy sector in Hawaii to meet the goal of 70\% clean energy use by 2030 .

HCEI was set up to be an ongoing, collaborative effort, and one of the first steps was the creation of working groups, composed of leaders from Hawaii government, stakeholders, businesses, and DOE. The working groups requested that Booz Allen Hamilton develop a high-level analysis of how 70\% clean energy could be achieved-this is referred to as the Hawaii Clean Energy Initiative Scenario Analysis ${ }^{4}$ and is frequently referred to as the "wedge" analysis. The wedge analysis, detailed under separate cover 4 informs the context for the project.

In October 2008, HECO entered into an energy agreement with the State of Hawaii, signed by the Governor, the Division of Consumer Advocacy, and witnessed by DBEDT and DOE as part of HCEI. This agreement puts HECO on the path to generate $40 \%$ of its electricity from renewable resources by 2030. Pursuant to this agreement, in June of 2009 , aggressive RPS goals were established by law that ultimately require $40 \%$ of HECO's electricity be generated from renewable sources by 2030 (10\% by $2010,15 \%$ by 2015 , and $25 \%$ by 2020). As an existing state law, the RPS was viewed as a constraint for the scope of this work when considering alternatives.

In 2009, recognizing the potential of the Big Wind project to contribute to the RPS goals, a series of studies regarding the technical feasibility of integrating the Big Wind project into the Oahu grid without compromising system reliability were initiated. These studies are collectively referred to as OWITS. 


\subsection{OWITS and the Technical Review Committee}

As part of OWITS, NREL, through funding provided by DOE established a Technical Review Committee (TRC) to provide technical review of the methodologies and approach used in the OWITS studies. The TRC consisted of regional, national, and international experts in the field who met in five separate sessions through the study period. Summary reports are available regarding the work and conclusions, which were relied upon for this economic study ${ }^{3}$.

In early 2010, through the work being done under OWITS and the TRC, there became a tangible understanding of technical feasibility for the project. Further, some key areas of uncertainty-the cost and performance of the undersea cable system and the integration requirements on $\mathrm{Oahu}$ - had been bracketed through engineering analysis and industry input.

At the time this work was performed, no economic studies were published or available. Many "back of the envelope" calculations had been made, and much more rigorous evaluations were known to have been made by parties with an economic interest in the project, including the wind developers and HECO, but all were held closely as proprietary and confidential given the importance of the ongoing and anticipated competitive procurement activities for the project. This study was intended to provide a common reference point for a diverse set of project stakeholders.

\section{APPROACH AND METHODOLOGY}

At the start of this work, several statements of purpose were influential on our choice of analytic methods:

- We are seeking to inform an incremental decision (Go Forward/Stop) vs. an execution decision (Go/No Go).

- Should the incremental investment decision be supported, we are seeking a sensitivity analysis to screen for key economic drivers and inform incremental investments.

- We want to enable a simple comparison of the costs of project alternatives.

- We want to consider on the basis of project risk (opportunity cost of capital) vs. financing costs.

Based on the goals and purpose of the analysis, and the early-stage nature of the project, we chose to use NPV methodology. This approach provides a clear indication for incremental decisions, based on + or - NPV; it provides a simple way to conduct sensitivity to key inputs; and it incorporates a measure of costs and benefits. Also, by choosing NPV analysis, which incorporates the concept of the opportunity cost of 
capital, we are running the analysis based on the risk of the project vs. the costs of financing, which can misinform early project development decisions by skewing the concept of project risk in a variety of ways.

\section{Other Comments Regarding Our Approach}

1. The analysis is done with the expectation that it is the first in a series of future, more refined iterations.

2. Inputs will be defined and further developed in future iterations, and economic motivation continually re-evaluated as the project nears full commitment and a Go/ No Go decision.

3. The analysis looks at the components of the Big Wind project as a whole.

\subsection{Project Development Context}

The National Renewable Energy Laboratory's (NREL) Project Development and Finance Section utilizes a project development framework in its approach to new project assessment and development. Modeled after commercial practices, the framework supports a systematic, iterative approach to disciplined project development. Under this framework, there are seven key areas of interest, categorized as follows: Site, Resource, Off-take, Permits, Technology, Team, and Capital. The acronym SROPTTC is used to refer to this collection of project fundamentals.

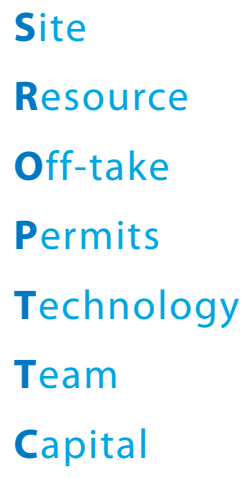

Using the SROPTTC framework, projects are analyzed iteratively to define key information gaps or project drivers on which the economic or technical feasibility of the project depends. Investment in time, money, and other resources is then directed to those key areas. After making that incremental investment, the project is subjected to the next iteration of review through the SROPTTC framework and judged once again on feasibility; the process is repeated through the entire development stage.

Mapping where a project stands in time is essential to making decisions. 
As shown conceptually in Figure 1, the Big Wind project is in the early stage of development. The analysis in this report should be considered in this context.

\section{Project Development Environment}

An Iterative Analysis Framework-BWC

\section{First Iteration \\ Back of envelope 2009 estimated cost $\$ 2.5 B$ \\ Second Iteration \\ NREL Analysis, 2010 \\ Introduces NPV}

\section{Third Iteration}

NREL Analysis, 2011

NPV with better inputs, expected 2012

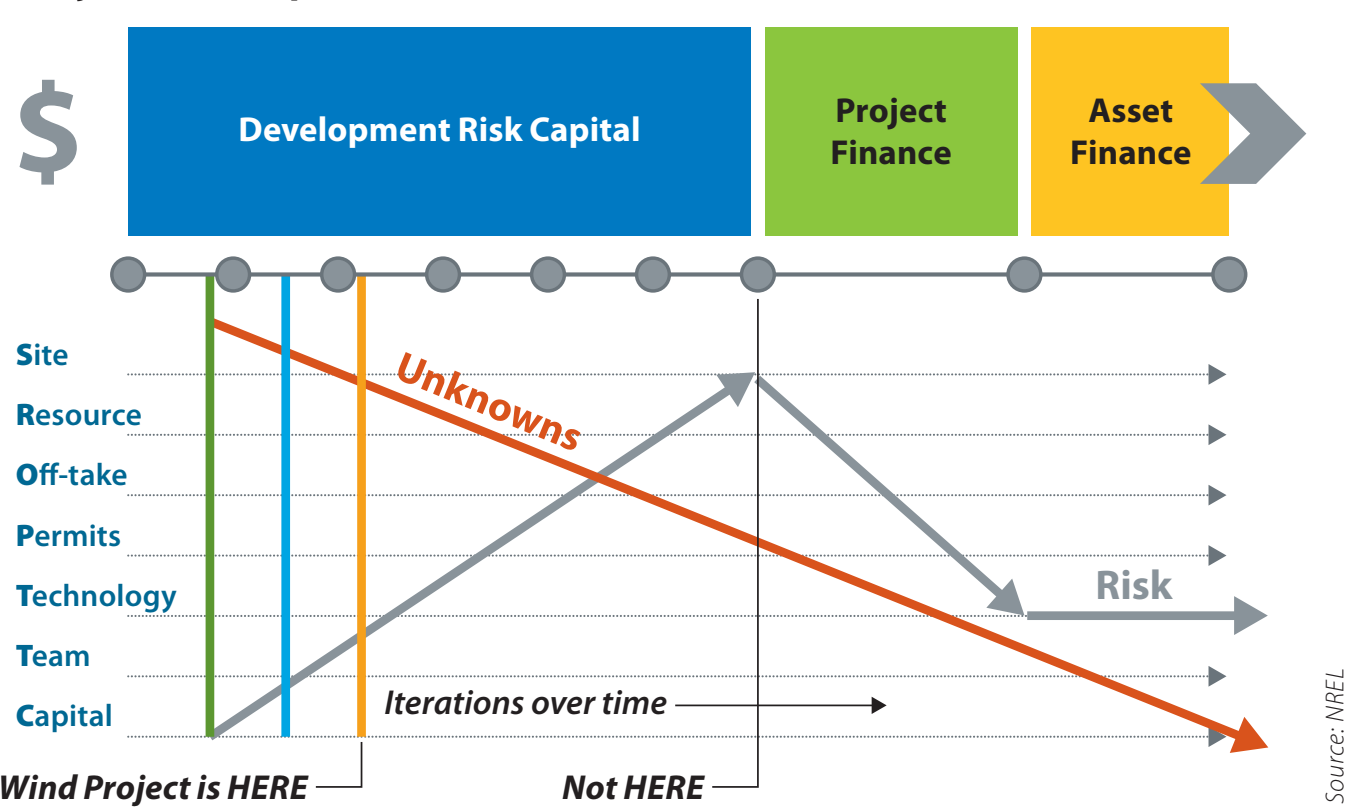

Figure 1. The Big Wind project shown in the SROPTTC framework

The Big Wind project is ambitious in scope and scale, and yields significant promise to deliver up to $20 \%$ of Oahu's clean energy needs, as defined by the state RPS. Accordingly, significant resources are necessary to move the project forward, from many stakeholders, including, but not limited to: State of Hawaii (Department of Business, Economic Development and Tourism (DBEDT) and others), Hawaiian Electric Company (HECO), Hawaii Natural Energy Institute, Public Utilities Commission (PUC), the U.S. Department of Energy (DOE), community entities, and the private sector. For each stakeholder facing an investment decision regarding this project, the recurring question will be: Am I motivated to make this investment?

Fundamentally, project motivation needs to be established and maintained. We are not seeking certainty - it takes significant investment to achieve that, but simply the motivation to make incremental investments toward certainty. A successful project development process depends on this principle, as shown in Figure 2. Once a project loses sufficient motivation it will more than likely fail to make progress and falter. In addition, without the ability to score and track collective motivation levels, a project will often lose direction and fail. 
It is typical to measure or score project motivation in financial terms; net-present value (NPV) is a common tool and is used in this analysis. The theory is that all aspects of the project can be represented in financial terms and, through the use of a pro forma, can be measured and tracked over time. This is not entirely true in all circumstances, but it does generally provide a consistent, rolled-up measure of relative project motivation.

The process is both iterative and cumulative as additional information is acquired and unknowns are eliminated. The confidence level associated with project motivation increases as incremental investments are made and the project becomes more defined. In general, more motivation (higher NPV) is needed at the earliest stages of development because of uncertainty. As confidence and definition grow, lower levels of motivation (NPV) are required to keep the project going.

All of these concepts set the stage for the context and purpose of this economic analysis, and the conclusions of the analysis should be considered with these in mind.

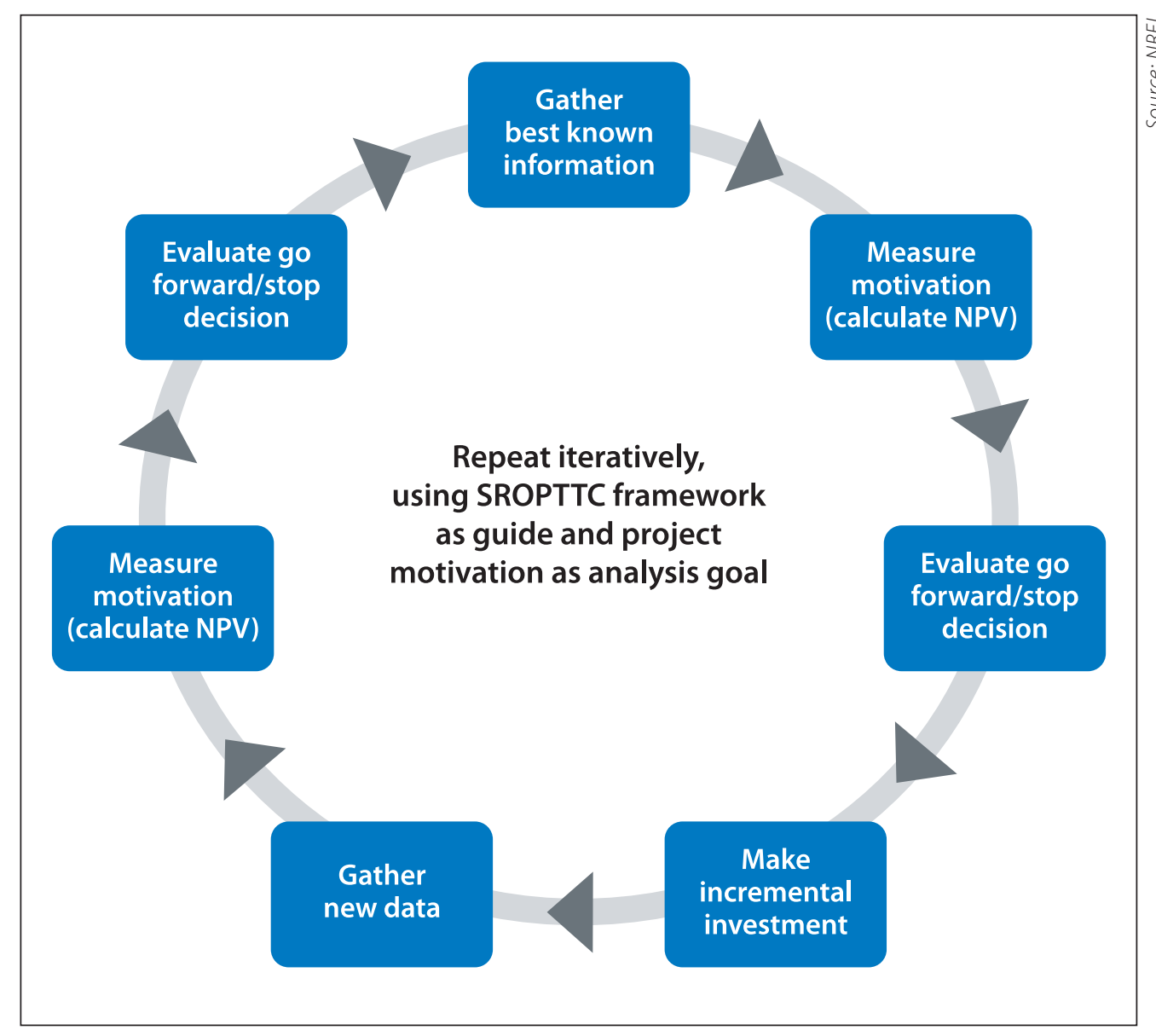

Figure 2. Project development process 


\section{BIG WIND PROJECT DEFINITION}

The concept of the so-called Big Wind project has been defined to include the following elements:

1. $400 \mathrm{MW}$ of wind power located on the islands of Lanai and Molokai.

2. Undersea inter-island cable(s) system and any required alternating current/direct current converter stations.

3. Grid improvements required to integrate the power onto the grid.

Many variations of the ultimate design and configuration of Big Wind are conceivable, and the ultimate design will be driven by a multitude of variables that drive cable system layouts and wind farm configurations. It was beyond the scope of this work to attempt an analysis of all the possible permutations of Big Wind, and not advisable to do so. In response, we used judgment and the information at hand to make reasonable assumptions to establish an economically representative project configuration.

\subsection{Wind Farms}

Our approach included the consideration of which wind farm configuration provides the most robust generation system, including diversification of wind resource and equipment and what gives the strongest test to the project economics (not necessarily the low-cost alternative). The result was to choose the "middle of the road" option that assumes 200 MW of capacity on both Molokai and Lanai.

\subsection{Cable System(s)}

By early 2010, a draft report entitled Oahu Wind Integration and Transmission Study (OWITS), Hawaiian Islands Transmission Interconnection Project had been delivered to NREL by Electranix, and had narrowed the cable system routing options down to six through technical analyses.

We relied on this report, and made the decision to select an option that would provide reasonable representation of likely cost vs. routing or performance criteria, both of which are beyond the scope of this work.

Based on this approach, the cable configuration and corresponding cost chosen was Stage 1 of "Option B1-2" of the Electranix OWITS Report 5 . This option carried a cost estimate that is on the high end at approximately $40 \%$ greater than the lowest cost option, but not the highest, of the cost range developed through industry inquiries and the experience of NREL and Electranix. It also represents our selected wind farm configuration - a transmission system supporting $200 \mathrm{MW}$ of wind on each island. Therefore, in our judgment it offered a reasonable representation of system cost to be used in our analysis. 
The option analyzed is defined as follows:

1. $200 \mathrm{MW}$ of wind capacity on each island.

2. Cable connects Lanai and Molokai to Oahu independently of one another (see Figure 3. Cable configuration used for this analysis-Electranix Option B1-25).

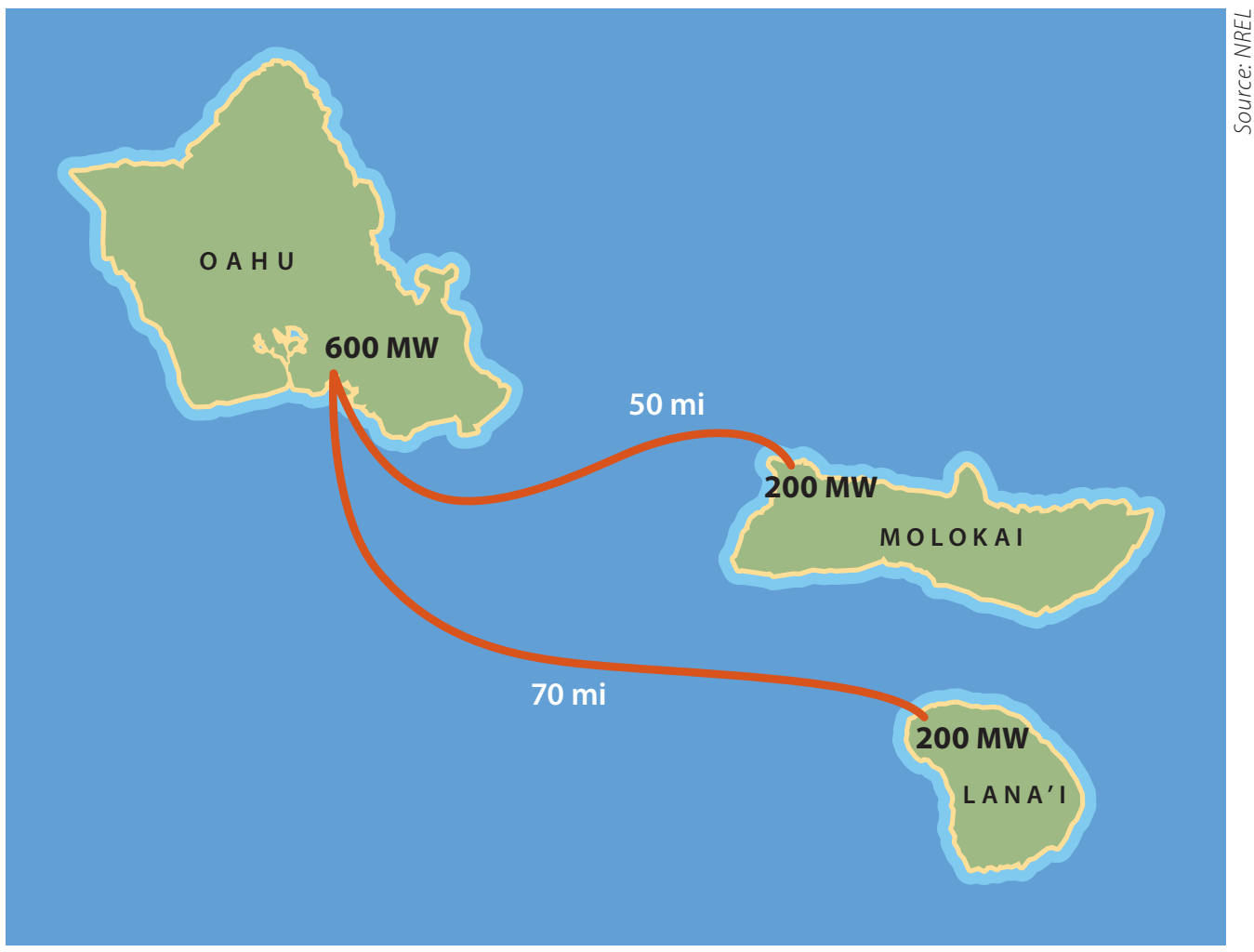

Figure 3. Cable configuration used for this analysis - Electranix Option B1-2

\subsection{Grid Improvements}

While the grid improvements necessary to physically link the wind power from Big Wind into the HECO grid depend a great deal on system configuration, any configuration coming onto Oahu would likely include land acquisition, improvements to substation(s), other upgrades to the existing system, and additional land-base transmission lines or upgrades to existing lines, etc.

It was our approach to use a generic representation of these costs, not one linked to any specific connection scheme, as described in Appendix C. 


\section{PROJECT ALTERNATIVES}

To consider the economic merits of investing in any project, alternatives to the project must be considered. We have to ask: is there another alternative that produces the same result as Big Wind (satisfies RPS to the same degree), which is economically advantageous, and should be pursued in place of Big Wind?

Before drawing any conclusions, we needed to establish what viable alternatives might be available that contributed to the RPS at the same scale as Big Wind on a megawatt hour (MWh) basis. We relied upon fundamental work and content of the HCEI Scenario Analysis ${ }^{4}$, and using that as a guide, we first established the following constraints:

- Sources of renewable energy on Kauai and Hawaii would involve fundamentally different costs and challenges regarding transmission, and so were not considered viable alternatives to Big Wind at this time.

- Sources of renewable energy on Maui are anticipated to be investigated in additional studies and may offer potential to be of such quantity and economic value that they may be a viable alternative to Big Wind.

With these constraints in mind, we will consider the available alternatives to Big Wind as follows 8 :

1. Biomass Resource. The limited biomass resource estimated on Oahu, Lanai, and Molokai (25 MW) does not have the apparent scale to be an alternative to Big Wind, though it's an important resource to deploy.

2. Wind on Oahu. The available wind resource on Oahu (65-100 MW) does not have the apparent scale to be a viable alternative to Big Wind, though it's an important resource to deploy.

3. Geothermal on Oahu. There is no identified geothermal resource on Oahu, and therefore it is not a viable alternative to Big Wind.

4. Hydro Power on Oahu. There is no identified hydro power resource on Oahu, and therefore it is not a viable alternative to Big Wind.

5. Rooftop Solar on Oahu. Rooftop solar on Oahu is shown to be a considerable potential source of renewable energy (992 MW); the scale of the solar resource is not a constraint, therefore rooftop solar is worth considering as an alternative to Big Wind. 
6. Utility-scale Solar on Oahu. Although utility-scale solar is not shown to be a considerable resource by the wedge analysis ( $8 \mathrm{MW}$ ); it is known that 40 to $50 \mathrm{MW}$ of utility-scale solar is currently under contract negotiations.

7. Municipal Solid Waste (MSW) and Landfill Gas. The limited MSW resource estimated on Oahu (57-75 MW) does not have the apparent scale to be an alternative to Big Wind, though it is an important resource to deploy.

8. Ocean Energy. Though it is assumed that the ocean energy resource potential is massive, the ability to capture and convert it reliably at significant scale has not yet been proven; it is not, therefore, considered a viable alternative to the Big Wind project today, but may well be an important source of energy for Hawaii in the future.

9. Biofuels. Biofuels as replacement fuels for petroleum-based liquid fuel in HECO's existing generators were not considered in the HCEI Scenario Analysis, but could provide an alternative to the resources listed above for HECO to satisfy the RPS. Biofuels could be derived from indigenous agricultural production in Hawaii and/or by import from foreign sources at whatever scale would be necessary to satisfy the RPS; therefore on the basis of scale and characteristics, the use of biofuels was included as a potential alternative to Big Wind.

From this information, it was clear that solar (both rooftop and utility-scale) and biofuels emerge as possible alternatives to Big Wind without restriction by resource or technology. On this basis, we considered each one in more detail.

\subsection{Further Discussion of Selected Alternatives}

\subsubsection{Biofuels}

Liquid biofuels, which meet the requirements of the RPS, are available in the marketplace at the scale required to compete with Big Wind (though some portion will be from imported, foreign sources). These fuels can be replacement fuels for the existing petroleum-based fuels used in HECO's generating plants, and therefore are considered a possible alternative; we will consider the economics of biofuels at a very high level later in this report. 


\subsubsection{Solar}

Solar power and wind power are fundamentally different resources and introduce different characteristics to the utility operating system. These differences stem from many factors including, but not limited to, resource variability, time-of-day production, and integration concerns with regard to system reliability and voltage stability. It is partly because of these differences that a portfolio approach is recommended by HCEI, whereby contributions of solar and wind power are more likely to be complementary than mutually exclusive or competitive.

\subsubsection{Rooftop Solar}

Based on the HCEI Scenario 8 for Oahu conducted in early 2009 (see Appendix A), solar power is clearly identified as an important resource, contributing approximately $21 \%$, or 1,030,000 MWh of the 4,841,000 MWh estimated to be necessary to meet the RPS on Oahu. In terms of overall scale, this compares favorably to the 1,480,000 MWh estimated to be delivered by Big Wind (at $400 \mathrm{MW}$ of installed capacity vs. $800 \mathrm{MW}$ shown in Scenario 8). The assumptions behind that level of power generation for solar include:

1. $50 \%$ of commercial building rooftops have a 100-kilowatt $(\mathrm{kW})$ system installed.

2. $50 \%$ of residential building rooftops have $2-\mathrm{kW}$ system installed.

Rooftop solar power cannot, however, be "double counted"- that is it cannot be used as an integral part of the solution in addition to Big Wind and also be considered as an alternative to Big Wind without more than doubling the scale of deployment expected. A rooftop solar penetration rate of $100 \%$ is an unreasonable expectation, so any additional use of the solar resource would be expected from utility-scale projects (discussed below).

It seems clear that the RPS will require high levels of rooftop solar be deployed in addition to Big Wind, and therefore cannot be used in place of Big Wind. For this reason, we exclude rooftop solar as a viable option to pursue as a direct replacement to Big Wind and make the assertion that rooftop solar is as essential to the solution as Big Wind is and should be pursued concurrently.

\subsubsection{Utility-scale Solar}

Utility-scale solar is considered at a relatively small scale in Scenario 8 for Oahu, with $8 \mathrm{MW}$ of capacity assumed to be installed, producing 16,000 MWh. At the time of this publication, $40-50 \mathrm{MW}$ of utility-scale solar is known to be currently under contract negotiation or regulatory approval. As shown in Appendix A, it is estimated that to produce 1,480,000 MWh would require between $500 \mathrm{MW}$ and $900 \mathrm{MW}$ of 
installed capacity, depending on the technology and configuration installed. Two constraints need to be considered relative to deployment of utility-scale solar technologies at this scale: (1) land resources and (2) integration and reliability constraints (technical feasibility).

The land area required for the installation of $500 \mathrm{MW}$ to $900 \mathrm{MW}$ of solar power is estimated to be between 4,500 and 5,000 acres, or roughly 8-square-miles of land. These calculations are all based on the utilization of Oahu's best solar resource, which exists along the southern coast, generally west of Honolulu in the area of Ewa. Alternatively, development could occur at this scale in a lower resource area like the agricultural lands of the central valley, but would require even more land area to produce the same output.

Land use is clearly a serious constraint on the potential for utility-scale solar to be considered at a scale that would make it an alternative to Big Wind. We also acknowledge that land use on Molokai and Lanai would also be impacted by the Big Wind project, and that will be an important consideration to the local community.

The technical and reliability implications of integrating $500 \mathrm{MW}$ to $900 \mathrm{MW}$ of solar power on the Oahu grid is simply not known, and is well beyond the limits of experience for the industry. Because solar is such an important resource to Hawaii and to the United States, the issue of large-scale solar power integration is currently being studied in an effort of similar design and scope to OWITS; it is called the Oahu Solar Integration Study.

Solar power is a key contributor to Hawaii's energy future and should be pursued to the limits of feasibility. Based on the constraints discussed above, the case cannot be made that solar poses a viable alternative to Big Wind to the degree that Big Wind should be abandoned and solar should be pursued exclusively. In fact, there is a clear case for significant deployment of both rooftop and utility-scale solar projects and Big Wind as complementary resources necessary to accomplish the Hawaii's goals.

\subsection{Conclusions}

We will later look at an economic comparison between solar, biofuels, and Big Wind, ignoring the constraints discussed above, to verify whether the economic case for solar and/or biofuels is so compelling as to change our conclusions here. 


\section{BIG WIND ECONOMIC MODEL}

As noted earlier, we chose a simple NPV approach to look at the fundamental project economics. This approach provides a clear indication of the conditions necessary for economic performance, and is conducive to sensitivity analysis of inputs, providing very useful output meeting the goals and purpose of this study. The relative values of NPV will provide feedback to inform the incremental decisions (Go Forward/Stop), and the results of sensitivity will inform where to focus those incremental investments.

Our approach was to input the best information available regarding the costs to implement and operate the major project components, and then solve for the amount of revenue required to generate a positive NPV. Upon investigation of the best available data in terms of cost inputs, we found a high degree of uncertainty typical to early-stage feasibility analysis. To compensate for this, we chose to solve for a level of revenue that produced an NPV that was substantially positive. This provides some conservatism and is appropriate given the project's stage of development.

A detailed discussion of the major elements of this model, and the inputs used, can be found in Appendix B.

\subsection{Initial Results and Interpretation}

When the inputs discussed in Appendix B were entered into the NPV model and a first-year-revenue of approximately $\$ 200 /$ MWh was applied, the NPV was calculated to be (approximately):

$$
N P V=+\$ 300,000,000
$$

A positive NPV means that given the set of inputs used, the project returns more than the required cost of capital, with excess value of approximately $\$ 300$ million in present value terms. Another way to think about this is that the project capital expenditures could cost up to $\$ 300$ million more than predicted and have an NPV equal to 0 , which means the project is meeting its obligations and is generally considered to be economic (depending on the confidence levels surrounding the inputs). This $\$ 300$ million positive NPV represents an additional level of conservatism to mitigate uncertainties, and is in addition to the $15 \%+$ /- range applied to the results.

We also calculated the levelized cost of electricity (LCOE) as defined by the user's manual for NREL's System Advisor Model (SAM) ${ }^{6}$. In the case described above, the LCOE was $\$ 220 / \mathrm{MWh}$.

\subsubsection{Caveats and Interpretation}

1. The analysis is highly input-sensitive, so our confidence in the result should be tempered by our confidence in the validity of the inputs used and the conservative factors applied to mitigate this uncertainty. 
2. Many simplifying assumptions are used; this is appropriate and necessary at this early stage of assessment, but should be considered as additional sources of error.

3. Given all of the above, interpretation of the results in a range (i.e. $15 \%+/-$ ) is appropriate, in addition to the $\$ 300$ million in excess value represented in the NPV value itself.

4. Use of this result should be limited to the stated purpose of this analysis.

\begin{tabular}{|c|c|c|}
\hline INPUT VARIABLE & INITIAL INPUTS & COMMENTS \\
\hline \multicolumn{3}{|c|}{ MARKET FACTORS } \\
\hline Year 1 Revenue $\$ / M W h$ & $\$ 203$ & Rising with annual inflation \\
\hline Discount Rate & $12 \%$ & Opportunity cost of capital \\
\hline Inflation (\%) & $2.25 \%$ & Assumed long-term inflation rate \\
\hline \multicolumn{3}{|c|}{ PERFORMANCE FACTORS } \\
\hline Projected Conversion/Line Losses (\%) & $3.9 \%$ & Sourced from OWITS/TRC \\
\hline System Availability (\%) & $1.1 \%$ & Sourced from OWITS/TRC \\
\hline Wind Curtailment (MWh/year) & $-90,000$ & Sourced from OWITS/TRC \\
\hline Delivered Energy Capacity Factor (\%) & $42.29 \%$ & Sourced from OWITS/TRC \\
\hline \multicolumn{3}{|c|}{ CAPITAL COST FACTORS } \\
\hline Wind Farm \& Connect (\$2.8M/MW) & $\$ 1,120,000,000$ & 2009 national average $\times 1.32$ \\
\hline Cable/Conversion Hard Costs (\$) & $\$ 533,00,000$ & From OWITS industry responses \\
\hline Cable/Conversion Soft Costs (\$) (10\%) & $\$ \quad 53,300,000$ & Added factor by NREL \\
\hline Oahu Grid (\$) & $\$ 205,000,000$ & Representative cost, by HECO \\
\hline 20-year residual value (\%) & $30 \%$ & Estimate \\
\hline \multicolumn{3}{|c|}{ OPERATIONAL COST FACTORS } \\
\hline Grid Ops Impact Costs (\$/MWh) & $\$ 15.00$ & NREL subject matter expert \\
\hline Annual O\&M (\$/MWh) & $\$ 13.50$ & From industry sources \\
\hline PROJECT NPV & LCOE (\$/MWH) & COMMENTS \\
\hline$\$ 299,924,209$ & $\$ 220$ & Expected values range $+/-15 \%$ \\
\hline
\end{tabular}

\subsubsection{Initial Conclusion}

Given the inputs detailed in Table 1, a positive NPV considered in isolation can be interpreted to support continued investment in the Big Wind project. As discussed earlier, Big Wind is not being considered in isolation, and in fact we will do a comparative analysis with the previously identified alternatives to Big Wind to characterize the expected performance of these alternatives. 


\subsection{Reasonableness Check}

Evaluating the reasonableness of the initial results in the context of energy economics in Hawaii is useful prior to moving forward with alternatives and sensitivity analyses.

It is important to note that the scope of this study did not include the kind of detailed utility system-modeling software necessary to determine specific anticipated economic impacts with and without the project; instead, the study seeks to inform the decision to make the incremental investment necessary to accomplish this kind of intensive work.

Acknowledging this limitation, we concluded that the expected value of $\$ 200 / \mathrm{MWh}$ is reasonable for continued consideration based on the following comparisons and context:

1. The anticipated costs are within the range of HECO's filed monthly avoided energy costs over the past few years. These costs ranged from a low of \$115/MWh in May 2009 , to a high of about $\$ 235 / \mathrm{MWh}$ in November 2008. While avoided costs are not the basis upon which renewable projects are deemed to have merit within Hawaii's regulatory and legal environment, this provides context for comparison and to judge the reasonableness of the costs.

2. The anticipated costs of photovoltaics (PV) are within the range of Tier 3 feed-in tarriffs proposed to the PUC by HECO, ranging between $\$ 197 /$ MWh and $\$ 236$ / MWh. Due to its size, this project does not qualify for this rate, and it is being used here for context and comparison.

\subsection{Limited Scope of Value for Cable}

The cable portion of the project provides great opportunity to add additional value to the utility system that is not recognized in the financial analysis but should be mentioned. While Big Wind "pays" for the entire capacity of the transmission, 50\%-60\% of that capacity is unused by Big Wind as configured today on an annual basis. This provides the opportunity for additional benefits, such as (but not limited to):

- Additional energy transmission (both renewable and conventional).

- Reliability improvements and reduced reserve requirements, if connected with Maui Electric Company (MECO) at an additional marginal cost.

- Communication connections, at marginal cost.

- Emergency operation/contingency opportunities between MECO and HECO. 


\section{ECONOMIC ANALYSIS OF ALTERNATIVES}

As discussed earlier, two options have been identified that could potentially provide the large scale needed ( 1.48 million MWh/year of renewable energy) using existing technology and available resource: solar energy technologies (three types) and electricity generated from biofuels.

The three types of solar energy we studied were: utility-scale fixed axis PV, utility-scale tracking PV, and utility-scale concentrated solar power. Distributed generation and rooftop were not considered because of the constraint of rooftop availability discussed in the Project Alternatives Section, and the fact that distributed PV is already used extensively in the assumptions of Scenario 8, the renewable program envisioned to satisfy the RPS.

The biofuels option identified considers using biofuels in existing generation facilities. It is important to note that these two technology options (solar and biofuels) are not necessarily mutually exclusive. However, to determine the relative economic viability of each option to attain the RPS goal, this analysis evaluates each option separately as a way of achieving an equivalent amount of renewable energy to Big Wind.

\subsection{Solar}

Based on these inputs, the same discounted cash flow model was used to determine NPV estimates for these alternatives. Inputs were generated by solar energy experts at NREL, using the well established methodologies provided in SAM.7 Details of the inputs used are provided in Appendix A.

We ran the expected economics of these alternative generation technologies with the same market-based inputs that were used in the Big Wind analysis. In particular, we used the same inputs for the cost of capital, first-year revenue, inflation rate, and integration costs incurred by HECO. By fixing these inputs, we generate a comparable NPV for each of the technologies that is technology-specific.

It is important to note that this methodology (imposing a cost of capital of 12\%) affects the resulting costs/NPV results for all the scenarios making the results useful for comparison within this study only. As an example, the local solar or wind markets will likely produce less risky, more fully developed commercial-scale project concepts with lower weighted average cost of capital due to the real cost of leverage and financing, thereby reducing the delivered price of energy. (See the discussion in Appendix B regarding "opportunity cost of capital.") 


\subsubsection{Incentives}

The availability of both state and federal government-backed incentives for various technologies have different policy horizons and, depending on project timing, may or may not be available. For conservatism relative to the Big Wind project, no incentives are applied to Big Wind in our analysis. We ran each of the solar alternatives with a representative collection of solar incentives applied to the project and without any incentives at all. This provides a more comprehensive view of the range of values that might be expected if the project(s) were executed in the next several years (with existing incentive policies in place).

The summary results of these calculations are presented in Table 2. Tables 5 through 8 in Appendix A detail the input parameters for each of the solar technologies.

\section{Table 2. Scenario Cost Outcomes}

\begin{tabular}{|c|c|c|c|c|}
\hline SCENARIO & $\begin{array}{c}\text { EXPECTED NPV, } \\
\text { NO INCENTIVES } \\
\text { (\$ MILLION) }\end{array}$ & $\begin{array}{l}\text { RANGE OF LCOE } \\
\text { WITHOUT } \\
\text { INCENTIVES }\end{array}$ & $\begin{array}{l}\text { EXPECTED NPV, } \\
\text { INCLUDING } \\
\text { INCENTIVES } \\
\text { (\$ MILLION) }\end{array}$ & $\begin{array}{l}\text { RANGE OF LCOE } \\
\text { WITH SUBSIDIES }\end{array}$ \\
\hline $\begin{array}{l}\text { Concentrated } \\
\text { Solar Power }\end{array}$ & $(\$ 2,785)$ & $\$ 493-\$ 667$ & $(\$ 574)$ & $\$ 272-\$ 368^{*}$ \\
\hline $\begin{array}{l}\text { Single Axis } \\
\text { Tracking PV }\end{array}$ & $(\$ 2,723)$ & $\$ 502-\$ 679$ & $(\$ 601)$ & $\$ 272-\$ 368^{*}$ \\
\hline Fixed Axis PV & $(\$ 3,034)$ & $\$ 527-\$ 713$ & $(\$ 727)$ & $\$ 289-\$ 391^{*}$ \\
\hline Big Wind & $\$ 299$ & $\$ 187-\$ 253$ & $\mathrm{~N} / \mathrm{A}$ & $\mathrm{N} / \mathrm{A}$ \\
\hline
\end{tabular}

* Solar LCOE figures shown here are heavily influenced by the $12 \%$ discount rate used in the NPV analysis, held constant to the wind project analysis to provide a consistent basis of comparison. LCOE are only useful for comparison purposes within this study and will vary from commercial project rates, which will generally be significantly lower.

Even with the assumption of significant subsidies for the installation of solar power, the "screening level" financials for Big Wind appear to be favorable in terms of NPV and LCOE compared with the solar alternatives. It is worth noting that this analysis does not include the cost or availability of land on Oahu, which would be a significant issue and additional cost to the solar project(s). The three commercial-scale solar variations would require approximately 5,000 acres of dedicated-use land. The Big Wind case does not include a specific value for land, though it may be assumed that the values used for capital and operating costs include land acquisition or leasing.

\subsubsection{Conclusion}

Given the constraints of large-scale solar discussed earlier, and the relative economics indicated here, a credible case was made that solar power is not an alternative investment opportunity to Big Wind, meaning Big Wind should be abandoned in favor of Big Solar. 


\section{We maintain our view that utility-scale solar and Big Wind are complementary, and investment should be made to pursue both concurrently vs. one exclusively over the other.}

\subsection{Biofuels}

A second alternative to the Big Wind project examined in this screening analysis is to generate an equivalent amount of renewable electricity from biofuels, where biofuels are either grown and refined in Hawaii, or imported similar to current oil imports. To maintain consistency, the same discounted cash flow model was used to compare the economics of replacing the renewable energy from Big Wind with energy generated using a biofuel in HECO's existing fleet of generators burning fuel oil today. As noted in the solar analysis previously, the specific numerical results of this analysis are valuable only when compared to other results in this study, and are not likely to be directly comparable to other studies (except for the general conclusions).

Biodiesel was chosen as the fuel because it is commercially available at significant scale today and the fact that HECO has tested and is currently using it in existing generating units. In addition, publicly available information sources provide data on the current cost of biodiesel to HECO on Oahu. Biodiesel has somewhat smaller energy content than fuel oil, which is accounted for in our calculations by adjusting the expected heat rate from HECO's reported average heat rate in terms of megawatt hours per barrels fuel consumed. This is not a detailed engineering study of performance, and the operating characteristics of the HECO generation fleet cannot be accurately predicted without such a study; however, given the scope and purpose of this analysis, it is representative of the relative economics of the alternatives being considered, and therefore useful in characterizing the economic choices we are seeking to inform. Different results may be attained for biocrude, which was not specifically studied herein.

To compare the use of biodiesel as a replacement to the Big Wind project, we calculate the barrels of biodiesel necessary to produce the same annual megawatt hours of electricity as Big Wind, and compare the expected annual costs of these purchases to the expected cost of electricity purchased from the Big Wind project. The result is an NPV where a positive indicates that the biodiesel has an economic advantage over Big Wind, and a negative indicates that biodiesel does not. The magnitude of the NPV is also informative as to how closely the economics compare.

The summary results of these calculations are presented in Table 3 . The inputs and references used in the modeling are described more fully in Appendix B. 


\begin{tabular}{|c|c|c|c|c|}
\hline SCENARIO & $\begin{array}{l}\text { EXPECTED NPV } \\
\text { (\$ MILLION) }\end{array}$ & $\begin{array}{l}\text { FIRST YEAR } \\
\text { BIOFUEL PRICE } \\
\text { \$/BARREL }\end{array}$ & $\begin{array}{l}2015 \text { ANNUAL } \\
\text { COST OF FUEL } \\
\text { PURCHASES } \\
\text { (\$ MILLION) }\end{array}$ & $\begin{array}{l}2015 \text { ANNUAL } \\
\text { COST OF BIG } \\
\text { WIND ENERGY } \\
\text { (\$ MILLION) }\end{array}$ \\
\hline $\begin{array}{l}\text { Current Biodiesel price } \\
\text { escalated at } 2.25 \% \text { annually }\end{array}$ & $(\$ 2,022)$ & $\$ 226.04$ & $\$ 675$ & $\$ 336$ \\
\hline $\begin{array}{l}\text { Current Biodiesel price with no } \\
\text { escalation }\end{array}$ & $(\$ 1,347)$ & $\$ 226.04$ & $\$ 617$ & $\$ 336$ \\
\hline $\begin{array}{l}\text { Fixed Biofuel price necessary } \\
\text { for breakeven }\end{array}$ & $\$ 0$ & $\$ 135.11$ & $\$ 369$ & $\$ 336$ \\
\hline $\begin{array}{l}\text { Inflated ( } 2.25 \%) \text { first year } \\
\text { Biodiesel price necessary for } \\
\text { breakeven }\end{array}$ & $\$ 0$ & $\$ 112.43$ & $\$ 336$ & $\$ 336$ \\
\hline
\end{tabular}

Two approaches were used in developing these results: both a breakeven $(N P V=0)$ analysis that defines the biodiesel costs necessary to match the costs of electricity generated by Big Wind, and a cost-based analysis using today's biodiesel prices paid by HECO either fixed or escalated at the rate of inflation used in all other scenarios analyzed (2.25\% annually).

It is apparent from these results that the concept of meeting the RPS by replacing the renewable electricity expected from the Big Wind project with that generated through the use of biodiesel exclusively is not economic for Hawaii. The analysis includes simplifying assumptions, and does not include a system-wide analysis and comparison of all of the operational impacts of the two alternatives, such as impacts and mitigants to reliability concerns. The assumption that more than 100 million gallons of biodiesel would be available annually at any price is also used here to simplify the analysis—-the United States has historically produced no more than 700 million gallons (as reported for 2008) in a given year ${ }^{13}$. It is not reasonable to assume, however, that further refinement of any of these assumptions can overcome a deficit of $\$ 2$ billion represented here.

\subsubsection{Conclusion}

Given the constraints of the analysis performed, the assumptions discussed earlier, and the relative economics indicated here, Big Wind should not be abandoned in favor of a strategy based solely on biodiesel.

We maintain our view that biofuels, and biodiesel in particular, is complementary to the Big Wind project, and investment should be made to pursue both concurrently vs. one exclusively over the other.

\section{SENSITIVITY ANALYSIS AND RESULTS}

At the early feasibility stages of a project, analysis is of great value to determine the project's sensitivity to the variation of key variables and to understand the relationship between those key inputs and the likely economic success of the project. Incremental investments can then be made against the key variables to improve the information on which management decisions can be made. 
Our methodology included isolating each variable and altering it until the project NPV was reduced to zero (i.e., reducing NPV from $+\$ 300$ million to zero). Each variable was then ranked against the others on the basis of the precent change it took to reach the breakeven point for the project (see Table 4). The lower the percent change required in the model input, the higher the project sensitivity to this individual variable's accuracy.

Based on these rankings (Table 4), we can consider which variables should be invested in today, and which do not materially influence decisions to purse the project at this early stage but will be important later in the development of the project as confidence intervals around key inputs are reduced.

On the basis of the sensitivity ranking shown in Table 4, it is clear that the project's economic performance is most sensitive to the uncertainty in the following inputs: capacity factor, discount rate, and wind farm capital expenditure (CAPEX). Year 1 revenue is also a key input, but in the case of our analysis, we were essentially solving for that number, and so it is not considered an input in the same way.

Table 4. Ranking and Relative Investment Priority of Key Project Economic Inputs

\begin{tabular}{|c|c|c|c|c|}
\hline INPUT VARIABLE & INITIAL INPUTS & $\begin{array}{c}\text { INPUT VALUE } \\
\text { REQUIRED } \\
\text { TO BREAK EVEN } \\
\text { NPV }=0\end{array}$ & $\begin{array}{l}\text { INPUT MARGIN } \\
\text { ON \% BASIS }\end{array}$ & $\begin{array}{l}\text { INCREMENTAL } \\
\text { INVESTMENT } \\
\text { PRIORITY }\end{array}$ \\
\hline Year 1 Revenue (\$/MWh) & $\$ 202.61$ & $\$ 174$ & $14 \%$ & \multirow{4}{*}{$\begin{array}{l}\text { HIGH PRIORITY } \\
\text { Project NPV has } \\
\text { highest sensitivity } \\
\text { to these inputs }\end{array}$} \\
\hline Capacity Factor (\%) & $42.3 \%$ & $35 \%$ & $16 \%$ & \\
\hline Discount Rate & $12 \%$ & $14.4 \%$ & $20 \%$ & \\
\hline $\begin{array}{l}\text { Wind Farm \& Connect } \\
\text { (\$/MW) }\end{array}$ & $\$ 2,800,000$ & $3,752,000$ & $34 \%$ & \\
\hline Cable/Conversion (\$) & $\$ 533,000,000$ & $\$ 883,500,000$ & $66 \%$ & \multirow{2}{*}{ MEDIUM PRIORITY } \\
\hline Inflation (\%) & $2.25 \%$ & $0.55 \%$ & $75 \%$ & \\
\hline Oahu Grid (\$) & $\$ 205,000,000$ & $\$ 586,300,000$ & $186 \%$ & \multirow{5}{*}{$\begin{array}{l}\text { LOW PRIORITY } \\
\text { Project NPV has } \\
\text { lowest sensitivity } \\
\text { to these inputs }\end{array}$} \\
\hline $\begin{array}{l}\text { Grid Ops Impact Costs (\$/ } \\
\text { MWh) }\end{array}$ & $\$ 15.00$ & $\$ 45.60$ & $204 \%$ & \\
\hline Annual O\&M (\$/MWh) & $\$ 13.50$ & $\$ 49.41$ & $266 \%$ & \\
\hline Salvage Value (\%) & $30 \%$ & $-\$ 3,500,000,000$ & $-509 \%$ & \\
\hline $\begin{array}{l}\text { Cable/Conversion } \\
\text { Engineering and } \\
\text { Management (\$) }\end{array}$ & $53,300,000$ & $\$ 403,181,000$ & $657 \%$ & \\
\hline
\end{tabular}

Note: The larger the delta associated with bringing the project to $N P V=0$, the more a variable has to change in order to materially impact the project. Thus, the lower the delta value in column four (such as $14 \%$ for first-year revenues) the higher the impact the variable has on the project's outcome. 
When we review the sources of these high-priority inputs, we are not surprised to find low confidence levels in the data sources, given the early stage of the project:

\section{Input Variable Source of Data}

Capacity Factor Output provided by TRC and HECO; not verified in terms of financials

Discount Rate Within range of unlevered tax equity returns quoted, not verified

Wind CAPEX $\quad 132 \%$ of 2009 national average cost-conceptual, no specific evidence

Cable CAPEX NREL/Electranix request for information—ballpark numbers, low number of responses.

It is clear that the project economics are highly sensitive to inputs about which we initially had relatively low levels of data to support assumptions. This is typical and completely expected for a project in the feasibility/conceptual stages and very importantly and significantly mitigated by the fact that we selected a positive NPV value that exceeded the required capital costs by $\$ 300$ million providing a conservative contingency to input uncertainties. The contingency is in addition to the $15 \%$ confidence interval, or range of values, applied to the expected outcome derived in the model. This provides an additional factor of safety and compensates for the confidence levels described here.

Any incremental investment made in Big Wind

ought to be made to increase the confidence levels we have

in the variables with the greatest sensitivity. 


\section{CONCLUSION}

The revenues required by the project are expected to be $\$ 200 / \mathrm{MWh}$ in the first year of operation, increased annually thereafter by $2.25 \%$. To this first-year value, we subjectively assign a confidence interval of $+/-15 \%$, giving a range of expected values between $\$ 170 / \mathrm{MWh}$ to $230 / \mathrm{MWh}$. Given a review of the energy economics in Hawaii today, this range of values was judged to be reasonable and not a barrier to the project's success.

Given the project definition, methodology, simplifying assumptions, the early stage of the project, and the relative uncertainty around the key inputs at this stage, we used a conservative approach in requiring the project to satisfy an NPV requirement of $+\$ 300$ million, significantly greater than a value of zero, which could be approached when inputs mature to a higher level of confidence.

Based on the results of our analysis, we find that further investment in the Big Wind project is warranted. The expected cost of energy from the project is reasonable with respect to (1) the context of the Hawaiian energy market today, and (2) viable alternatives to Big Wind that contribute at the same order of magnitude to the state RPS.

A review of the available alternatives to Big Wind was conducted, and started with both a review of the availability of renewable resources and/or the availability of mature, commercially available (and financeable) technologies. From this screening process, solar and biofuels were selected for further analysis. Both biofuels and solar are important resources to be considered in achieving the state RPS, but neither one presents a case strong enough to warrant abandonment of the Big Wind project. Further, considering the energy goals of the State of Hawaii and the requirements of the RPS, both solar and biofuels will be needed as complementary resources to be pursued along with Big Wind and the wide portfolio of other available renewable resources.

Given our finding that further investment in Big Wind is warranted, we conducted a sensitivity analysis of the key inputs, which indicated that any incremental investment made would be best directed at increasing the confidence in the following parameters of the project:

1. A more detailed understanding of the power production capability of the wind resource (capacity factor), as integrated into the Oahu grid.

2. A more detailed understanding of the capital costs of the three main areas of investment required: wind farms, cable transmission system, and Oahu grid improvements.

3. A more detailed and robust analysis of execution structures and the corresponding cost of capital for the project, a key driver of project economics. 


\section{OAHU Scenario Analysis: What does the HCEl analysis for Oahu include?}

- The scenario analysis is not meant to be prescriptive, it is meant to illuminate a realistic pathway to $70 \%$ clean energy

- Resource data was compiled from public sources such as DBEDT, utility plans, Hawaii Energy Strategy, HNEI, HARC, DOE, EIA, NREL

- Resources were loaded with an eye towards cost; projects were assumed to be site-able

\section{Scenario analysis background}

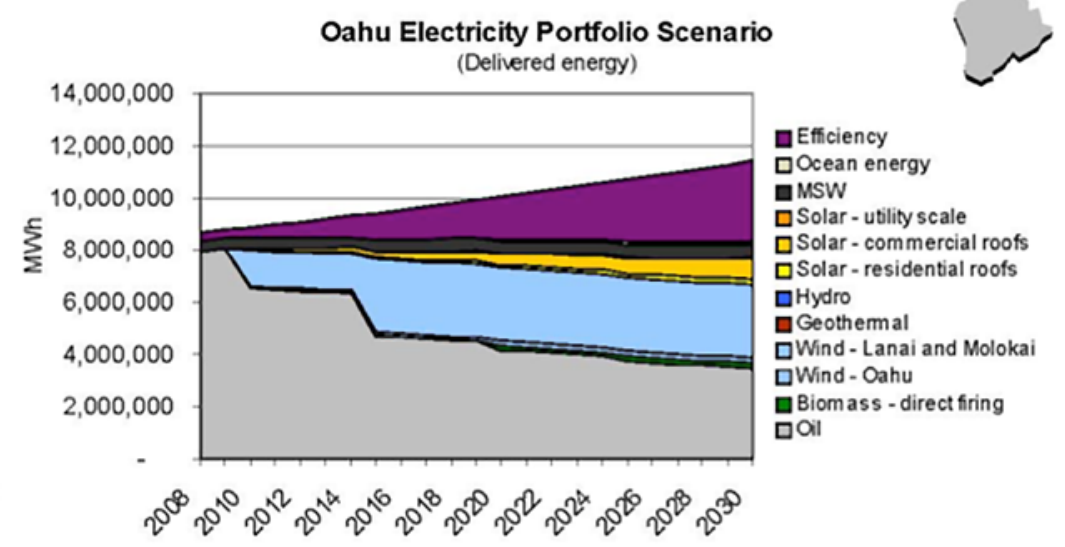

Oahu Electricity Portfolio Scenario (Delivered energy)

- The scenario explained below is the most aggressive of 8 scenarios developed, it is the only one that reached $70 \%$ clean energy in the electricity sector on Oahu. This scenario included high levels of energy efficiency and aggressive deployment of electric cars. The maximum level of clean energy that Oahu could reach with its local resources deployed to the maximum was $32 \%$ to $56 \%$. To bring Oahu to $70 \%$ clean energy in the electricity sector, additional scenarios included an undersea cable to bring wind energy to Oahu from Lanai and Molokai this is the case in the scenario outlined here.

\begin{tabular}{|c|c|}
\hline $\begin{array}{l}\text { Efficiency } \\
3,100,000 \mathrm{MWh} \\
\quad \text { in } 2030\end{array}$ & $\begin{array}{l}\text { Retrofits: About } 7,000 \text { homes and } 250 \text { commercial buildings retrofitted annually to } 20-50 \% \text { more } \\
\text { efficient; includes solar water on half of existing homes and } 10 \% \text { of commercial buildings. } \\
\text { New buildings: All new buildings } 30-40 \% \text { more efficient than conventional buildings starting in } \\
2010 \text { and } 50 \% \text { by } 2015 \text {. After } 2015 \text { all new buildings reach } 50 \% \text { efficiency, and are net zero energy } \\
\text { because on average they meet their annual energy needs with on-site distributed generation }\end{array}$ \\
\hline $\begin{array}{l}\text { Ocean } \\
150,000 \mathrm{MWh}\end{array}$ & $\begin{array}{l}\text { Projects: A } 50 \mathrm{MW} \text { ocean/wave project in Oahu is assumed to be deployed by } 2030 \text { [Average } \\
\text { capacity factor: } 35 \% \text { ] }\end{array}$ \\
\hline $\begin{array}{l}\text { MSW } \\
470,000 \mathrm{MWh}\end{array}$ & $\begin{array}{l}\text { Projects: Oahu is assumed to increase its municipal solid waste electricity output from current } 46 \\
\text { MW to } 77 \mathrm{MW} \text {, which is the maximum estimated resource potential [Capacity factor: } 95 \% \text { ] }\end{array}$ \\
\hline $\begin{array}{l}\text { Solar utility } \\
16,000 \mathrm{MWh}\end{array}$ & $\begin{array}{l}\text { Projects: NREL estimated that Oahu could support at least an } 8 \mathrm{MW} \text { project, which was deployed } \\
\text { in this scenario; it would require approximately } 50 \text { acres of land [Capacity factor: } 24 \% \text { ] }\end{array}$ \\
\hline $\begin{array}{l}\text { Solar roofs } \\
1,030,000 \mathrm{MWh}\end{array}$ & $\begin{array}{l}\text { - Commercial Roofs: Assume that half of Oahu's approximately } 10,000 \text { commercial buildings would } \\
\text { install rooftop PV, each system averaging } 100 \mathrm{~kW} \text { [Capacity factor: } 23 \% \text { ] } \\
\text { - Residential Roofs: Assume that half of the } 300,000 \text { housing units on Oahu would install rooftop } \\
\text { PV by } 2030 \text {, each system averaging } 2 \mathrm{~kW} \text { [Capacity factor: } 23 \% \text { ] }\end{array}$ \\
\hline Hydro & - No resource potential on Oahu \\
\hline Geothermal & - No resource potential on Oahu \\
\hline $\begin{array}{l}\text { Wind from } \\
\text { Lanai/Molokai } \\
2,800,000 \mathrm{MWh}\end{array}$ & $\begin{array}{l}\text { Projects: The maximum wind potential on Lanai and Molokai is assumed to be } 800 \mathrm{MW}-400 \mathrm{MW} \\
\text { on each island. The most technologically and economically feasible way to transfer this energy to } \\
\text { the load center of Oahu would be via an undersea cable [Capacity factor: } 45 \% \text { ] }\end{array}$ \\
\hline $\begin{array}{l}\text { Wind on Oahu } \\
200,000 \mathrm{MWh}\end{array}$ & $\begin{array}{l}\text { Projects: Reports estimate that the maximum wind potential on Oahu is } 65 \mathrm{MW} \text {. None of the } \\
\text { resource reports estimated offshore wind potential [Capacity factor: } 35 \% \text { ] }\end{array}$ \\
\hline $\begin{array}{l}\text { Biomass } \\
175,000 \mathrm{MWh}\end{array}$ & $\begin{array}{l}\text { Projects: Sources showed that the maximum biomass electricity generation potential on Oahu at } \\
\text { would be } 25 \text { MW [Capacity factor: } 80 \% \text { ] }\end{array}$ \\
\hline
\end{tabular}




\begin{tabular}{|c|c|c|c|c|c|}
\hline & $\begin{array}{l}\text { BIG WIND/ } \\
\text { CABLE }\end{array}$ & CSP & $\begin{array}{c}\text { PV } \\
\text { TRACKING }\end{array}$ & PV FIXED & PV \\
\hline & Option B1-2 & Utility-scale & Utility-scale & Utility-scale & Distributed \\
\hline Total Capacity (MW) & 400 & 489 & 682 & 890 & 890 \\
\hline Capacity Factor & $42.25 \%$ & $34.60 \%$ & $24.80 \%$ & $19 \%$ & $19 \%$ \\
\hline kWh Delivered to HECO & $1,481,903,000$ & $1,481,903,000$ & $1,481,903,000$ & $1,481,903,000$ & $1,481,903,000$ \\
\hline Total Project Cost* & $\$ 1,911,300,000$ & $\$ 5,265,289,436$ & $\$ 5,156,477,810$ & $\$ 5,589,924,663$ & $\$ 46,611,190,960$ \\
\hline Annual O\&M $(\$ / M W h)^{* *}$ & 28.5 & 57.66 & 62.54 & 58.82 & 53.82 \\
\hline Inflation & $2.25 \%$ & $2.25 \%$ & $2.25 \%$ & $2.25 \%$ & $2.25 \%$ \\
\hline $\begin{array}{l}\text { Draw Down Schedule (yr } \\
1 \% / y r 2 \% / y r ~ 3 \%)\end{array}$ & $30 / 50 / 20$ & $30 / 50 / 20$ & $30 / 50 / 20$ & $30 / 50 / 20$ & $5 \%$ annually \\
\hline Construction Period (years) & 2.5 & 2.5 & 2.5 & 2.5 & 20 \\
\hline $\begin{array}{l}\text { Single - Use Acreage } \\
\text { Requirement }\end{array}$ & - & 4,466 & 4,748 & 5,111 & - \\
\hline $\begin{array}{l}\text { Water Requirement (already } \\
\text { in costs for CSP) (Gal/yr) }\end{array}$ & - & $\begin{array}{l}1.5-1.6 \\
\text { billion }\end{array}$ & - & - & - \\
\hline
\end{tabular}

* Includes costs for transmission and distribution-solar options have placeholder costs equal to BW/C Oahu infrastructure costs from HECO (\$205 million, Leon Roose, HECO).

** Includes charges to reflect impact to utility operations to accept intermittancy, includes insurance.

No land costs are included in any scenario.

\begin{tabular}{|c|c|c|c|c|c|}
\hline \multicolumn{6}{|c|}{ CONSTRUCTION COSTS AS MODELED } \\
\hline & $\begin{array}{l}\text { BIG WIND/ } \\
\text { CABLE }\end{array}$ & CSP & $\begin{array}{c}\text { PV } \\
\text { TRACKING }\end{array}$ & PV FIXED & PV \\
\hline & Option B1-2 & Utility-scale & Utility-scale & Utility-scale & Distributed \\
\hline $\begin{array}{l}\text { Renewable Energy Plant } \\
\text { Cost—no land }\end{array}$ & $\$ 1,120,000,000$ & $\$ 5,160,289,436$ & $\$ 4,951,447,810$ & $\$ 5,384,924,663$ & $\$ 6,461,909,596$ \\
\hline $\begin{array}{l}\text { Cable/Converters }+10 \% \\
\text { Engineering/Management }\end{array}$ & $\$ 586,300,000$ & - & - & - & - \\
\hline $\begin{array}{l}\text { Oahu Grid Improvements/ } \\
\text { CAPEX }\end{array}$ & $\$ 205,000,000$ & $\$ 205,000,000$ & $\$ 205,000,000$ & $\$ 205,000,000$ & $\$ 150,000,000$ \\
\hline Total CAPEX & $\$ 1,911,300,000$ & $\$ 5,365,289,436$ & $\$ 5,156,447,810$ & $\$ 5,589,924,663$ & $\$ 6,611,909,596$ \\
\hline $\begin{array}{l}\text { Salvage Value } \\
\text { (\% of total costs, in 20th } \\
\text { year of operation) }\end{array}$ & $30 \%$ & $10 \%$ & $10 \%$ & $10 \%$ & $10 \%$ \\
\hline
\end{tabular}


Table 6. Fixed Axis PV Input Assumptions

MARKET FACTORS

\begin{tabular}{|c|c|c|}
\hline Year 1 Revenue $(\$ / M W h)^{9}$ & $\$ 202.61$ & Rising annually w/inflation \# \\
\hline Discount Rate & $12 \%$ & Opportunity cost of capital \\
\hline Inflation (\%) & $2.25 \%$ & $\begin{array}{l}\text { HECO avoided cost inflation } \\
\text { estimate }\end{array}$ \\
\hline \multicolumn{3}{|c|}{ TECHNOLOGY FACTORS } \\
\hline Capacity Factor (\%) & $19.0 \%$ & NREL/SAM \\
\hline Projected Conversion/Line Losses (\%) & 0 & Assumed part of capacity factor \\
\hline Total Installed Capacity (MW) & 890 & NREL/SAM \\
\hline Solar Curtailment (MWh/Year) & 0 & Assumed part of capacity factor \\
\hline Degradation of Solar Panels (\%/year) & $0.5 \%$ & NREL/SAM \\
\hline \multicolumn{3}{|c|}{ CAPITAL COST FACTORS } \\
\hline Fixed PV CAPEX (\$/MW) & $\$ 6,048,040$ & NREL/SAM \\
\hline Oahu Grid (\$) & $\$ 205,000,000$ & Added to represent integration costs \\
\hline Salvage Value (\%) & $10 \%$ & NREL_Plug \# \\
\hline \multicolumn{3}{|c|}{ OPERATIONAL COST FACTORS } \\
\hline Grid Ops Impact Costs (\$/MWh) & $\$ 15.00$ & NREL subject matter expert \\
\hline Annual O\&M (\$/MWh) & $\$ 43.82$ & NREL/SAM \\
\hline
\end{tabular}

\section{Table 7. Tracking PV Input Assumptions}

\section{\begin{tabular}{l|l|l} 
INPUT VARIABLE & INPUTS & SOURCE
\end{tabular}}

\begin{tabular}{l|c|l}
\hline & MARKET FACTORS \\
\hline Year 1 Revenue (\$/MWh) & $\$ 202.61$ & Rising annually w/inflation \# \\
\hline Discount Rate & $12 \%$ & Opportunity cost of capital \\
\hline Inflation (\%) & $2.25 \%$ & $\begin{array}{l}\text { HECO avoided cost inflation } \\
\text { estimate }\end{array}$ \\
\hline & TECHNOLOGY FACTORS \\
\hline Capacity Factor (\%) & $24.8 \%$ & NREL/SAM \\
\hline Projected Conversion/Line Losses (\%) & 0 & Assumed part of capacity factor \\
\hline Total Installed Capacity (MW) & 682 & NREL/SAM \\
\hline Solar Curtailment (MWh/Year) & 0 & Assumed part of capacity factor \\
\hline Degradation of Solar Panels (\%/year) & $0.5 \%$ & NREL/SAM \\
\hline \multicolumn{2}{c}{ CAPITAL COST FACTORS } \\
\hline Tracking PV CAPEX (\$/MW) & $\$ 7,258,856$ & NREL/SAM \\
\hline Oahu Grid (\$) & \$205,000,000 & Added to represent integration costs \\
\hline Salvage Value (\%) & $10 \%$ & NREL一Plug \# \\
\hline & OPERATIONAL COST FACTORS \\
\hline Grid Ops Impact Costs (\$/MWh) & \$15.00 & NREL subject matter expert \\
\hline Annual O\&M (\$/MWh) & \$47.54 & NREL/SAM \\
\hline
\end{tabular}




\begin{tabular}{|c|c|c|}
\hline INPUT VARIABLE & $\begin{array}{l}\text { INITIAL } \\
\text { INPUTS }\end{array}$ & SOURCE \\
\hline \multicolumn{3}{|c|}{ MARKET FACTORS } \\
\hline Year 1 Revenue $(\$ / M W h)^{11}$ & $\$ 202.61$ & Rising annually w/inflation \# \\
\hline Discount Rate & $12 \%$ & Opportunity cost of capital \\
\hline Inflation (\%) & $2.25 \%$ & $\begin{array}{l}\text { HECO avoided cost inflation } \\
\text { estimate }\end{array}$ \\
\hline \multicolumn{3}{|c|}{ TECHNOLOGY FACTORS } \\
\hline Capacity Factor (\%) & $34.6 \%$ & NREL/SAM \\
\hline Projected Conversion/Line Losses (\%) & 0 & Assumed part of capacity factor \\
\hline Total Installed Capacity (MW) & 489 & NREL/SAM \\
\hline Solar Curtailment (MWh/Year) & 0 & Assumed part of capacity factor \\
\hline Degradation of Solar Panels (\%/year) & $0.0 \%$ & NREL/SAM \\
\hline \multicolumn{3}{|c|}{ CAPITAL COST FACTORS } \\
\hline CSP CAPEX (\$/MW) & $\$ 10,554,442$ & NREL/SAM \\
\hline Oahu Grid (\$) & $\$ 205,000,000$ & $\begin{array}{l}\text { Added to represent integration } \\
\text { costs }\end{array}$ \\
\hline Salvage Value (\%) & $10 \%$ & NREL_-Plug \# \\
\hline \multicolumn{3}{|c|}{ OPERATIONAL COST FACTORS } \\
\hline Grid Ops Impact Costs (\$/MWh) & $\$ 15.00$ & NREL subject matter expert \\
\hline Annual O\&M (\$/MWh) & $\$ 42.67$ & NREL/SAM \\
\hline
\end{tabular}




\section{APPENDIX B}

\begin{tabular}{|c|c|c|}
\hline INPUT VARIABLE & $\begin{array}{l}\text { INITIAL } \\
\text { INPUTS } \\
\end{array}$ & SOURCE \\
\hline \multicolumn{3}{|c|}{ MARKET FACTORS } \\
\hline Year 1 Revenue (\$/MWh)a & $\$ 202.61$ & Equivalent with Big Wind \\
\hline Discount Rate & $12 \%$ & Opportunity cost of capital \\
\hline Inflation (\%)b & $2.25 \%$ & $\begin{array}{l}\text { HECO avoided cost inflation } \\
\text { estimate }\end{array}$ \\
\hline \multicolumn{3}{|c|}{ TECHNOLOGY/INPUT FACTORS } \\
\hline Capacity Factor (\%) & $\mathrm{N} / \mathrm{A}$ & $\begin{array}{l}\text { HECO reported system heat rate } \\
\text { used which incorporates usage } \\
\text { within fleet }\end{array}$ \\
\hline Projected Conversion/Line Losses (\%) & 0 & $\begin{array}{l}\text { No new transmission or conversion } \\
\text { necessary for biofuels }\end{array}$ \\
\hline $\begin{array}{l}\text { Annual Fuel Volume required } \\
\text { (barrels) }\end{array}$ & $2,730,475^{1}$ & $\begin{array}{l}\text { Calculated using energy content } \\
\text { adjustment and HECO heat rate }\end{array}$ \\
\hline $\begin{array}{l}\text { Annual Fuel Volume required } \\
\text { (gallons) }\end{array}$ & $114,679,940^{2}$ & $\begin{array}{l}\text { Calculated using energy content } \\
\text { adjustment and HECO heat rate }\end{array}$ \\
\hline $\begin{array}{l}\text { Overall System Sales Heat Rate using } \\
\text { biodiesel (MWh/bbl fuel) }\end{array}$ & $0.543^{3}$ & $\begin{array}{l}\text { Biodiesel energy content dis- } \\
\text { counted } 10 \% \text {, heat rate adjusted } \\
\text { accordingly }\end{array}$ \\
\hline $\begin{array}{l}\text { Average cost of biodiesel paid by } \\
\text { HECO year-to-date as of April, } 2011 \\
\text { (\$/bbl) }\end{array}$ & $\$ 226.04^{4}$ & As reported by State of Hawaii \\
\hline
\end{tabular}

\begin{tabular}{l|c|l}
\hline \multicolumn{3}{c}{ CAPITAL COST FACTORS } \\
\hline $\begin{array}{l}\text { HECO or others' capital investment } \\
\text { required to accept Biodiesel at-scale } \\
\text { required }\end{array}$ & $\$ 0$ & $\begin{array}{l}\text { Capital improvements ignored to } \\
\text { simplify analysis }\end{array}$ \\
\hline Oahu Grid (\$) & $\$ 0$ & No grid upgrades necessary \\
\hline Salvage Value (\%) & N/A & $\begin{array}{l}\text { Not applicable given other } \\
\text { assumptions }\end{array}$ \\
\hline \multicolumn{2}{|c|}{ OPERATIONAL COST FACTORS } \\
\hline Grid Ops Impact Costs $(\$ / M W h)$ & $\$ 0$ & Assumed for biodiesel \\
\hline Annual O\&M (\$/MWh) & $\$ 0$ & Assumed for biodiesel \\
\hline
\end{tabular}

a Year one revenue was calculated in the analysis for Big Wind. The same revenue is being used for all alternative scenarios to allow for direct comparison of NPV's for each technology option.

$b$ Inflation not used in all scenarios.

1 Value calculated using MWh necessary to replace Big Wind, and the estimated HECO heat rate using biodiesel.

2 Calculated using 42 gallons/barrel.

3 HECO Sales Heat Rate per testimony supporting Docket No. 2010-0080, adjusted down by $10 \%$ to reflect energy content penalty for biodiesel; conservative vs. CT heat rate with biodiesel.

4 As reported year-to-date biodiesel costs as reported by DBEDT as of April, 2011. http://hawaii.gov/ dbedt/info/economic/data_reports/energy-trends/Energy_Trend.pdf. 


\section{APPENDIX C}

\section{ECONOMIC MODEL DETAILED DESCRIPTION}

The following pages provide a detailed description of the major elements and inputs of the Big Wind NPV model, including discussion of the methodology and strategy behind the decisions made in developing the model.

\section{Timing/Study Period-20-Year Analysis}

The analysis includes 20 years of operation, with an additional 3 years of construction starting in 2011. The assumption of start-date is arbitrary in this case, and can be easily shifted over different timelines (there is no implied start date in 2011). At the end of the 20-year operating period, an assumption for the remaining value of the project is used (see "project residual value" below).

\section{Cost Estimates-General Discussion}

Values represented in the model are estimates and are meant to be representative of likely project costs in an effort to inform early-stage project decisions based on what was known at the time of the study (May 2010). Ultimate project costs will be significantly influenced by a variety of factors, including the timing of construction and market conditions in key areas including, but not limited to: undersea cable components and service providers, wind farm components and service providers, raw materials and commodities, capital markets, state and federal policy, and labor and equipment markets.

Recognizing the statements above, we reiterate that this analysis was not performed as a definitive financial analysis on which to base a true Go/No go decision for the project, but rather, to use available information and reasonable and necessary assumptions to inform decision makers and stakeholders concerned with incremental Go Forward/ Stop and investment decisions.

\section{Wind Farms}

The wind project locations are unique, and no public information is available to document the cost of installing large capacity wind farms in these isolated locations. The logistics of material, labor, and equipment are difficult to account for without detailed study, as are the site-specific development costs, including Island infrastructure (like port facilities and roadways) improvements; soil conditions and foundations; and community impact, environmental, or cultural concerns, all of which will have an impact on the installed cost of these projects. 
We needed a simplification and assumption of the fully developed cost of the wind farms, and turned to an annual report of the wind industry for recent installed cost information. Based on the 2009 Wind Technologies Market Report from DOE'2, the capacity-weighted national average installed cost of U.S. wind projects sampled and built in 2009 was $\$ 2,120,000$ per megawatt.

As an adjustment factor to the Hawaii market, we generated a number using RS Means 2008 cost data book by aggregating five different components to represent the unique situation of working on Lanai and Molokai. As a result of that calculation, we generated a cost adjustment factor of $132 \%$ from national average prices. When applied to the 2009 national average wind project installed costs from DOE we arrived at a representative cost for the wind projects of $\$ 2,800,000$ per megawatt.

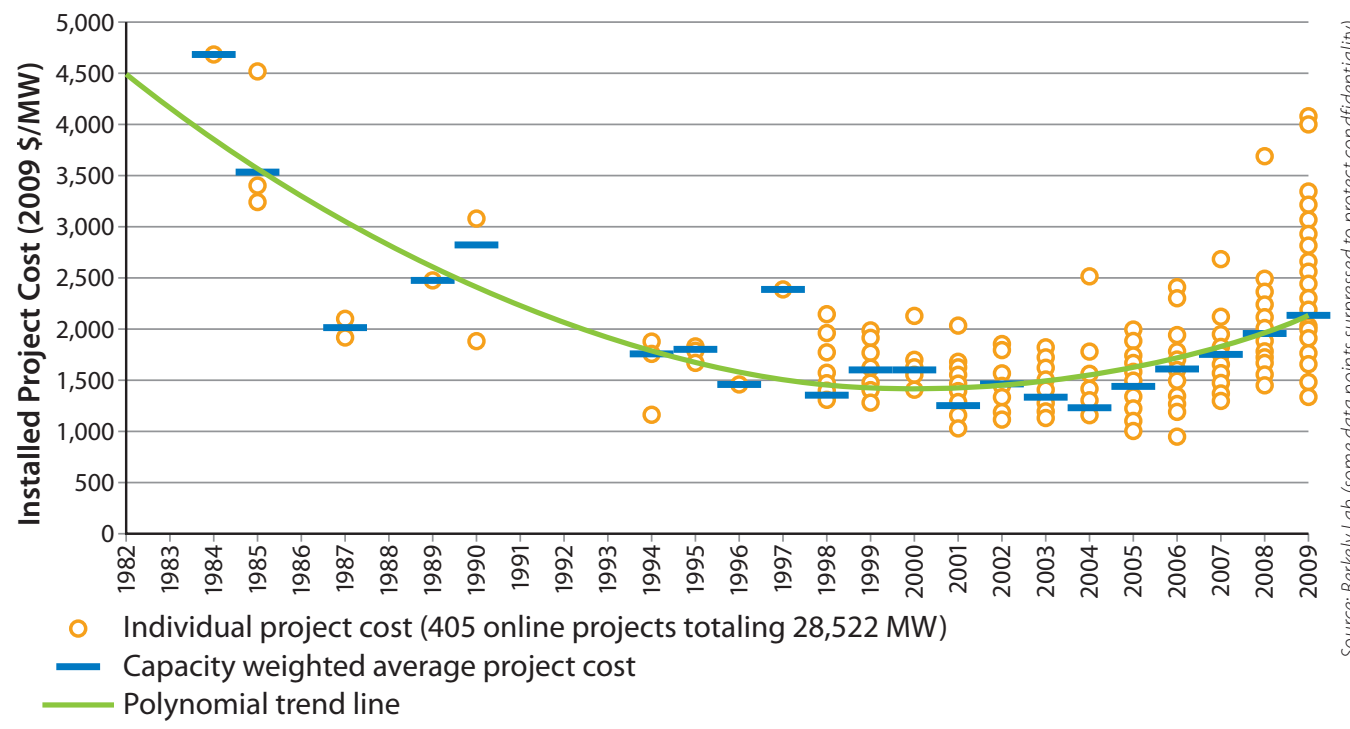

Figure 4. Installed wind power project costs over time ${ }^{12}$

\section{Undersea Cable System}

During the work performed under OWITS, Electranix and NREL issued a Request for Information to the industry requesting budget pricing information for undersea cable systems and components. This represented the best cost information available, and we relied on the methodology as described in the OWITS study.

Undersea cable project costs will vary widely depending on the layout and design of the system. As described earlier in this document, our purpose is to represent the economics of the project to motivate and inform further investment. For this reason, we looked at the distribution of costs related to the final six options presented by Electranix rather than the specifics of the physical layout or cable routing, technical design elements, or performance characteristics. A partial excerpt from the Electranix report for Stage 1 cable routing options is shown in Table 10. 


\begin{tabular}{|c|c|c|c|c|c|c|c|}
\hline OPTION & C3-2 & A3-2 & & -2 & B3-2 & C1-2 & B1-2 \\
\hline \multirow[t]{2}{*}{ Description } & \multirow[t]{2}{*}{$\begin{array}{l}400 \mathrm{MW} \\
\text { Koolau to } \\
\text { Molokai }\end{array}$} & \multirow{2}{*}{$\begin{array}{l}200 \mathrm{MW} \\
\text { Molokai to } \\
\text { Koolau, } \\
200 \mathrm{MW} \\
\text { Molokai to } \\
\text { Iwilei }\end{array}$} & \multicolumn{2}{|c|}{$\begin{array}{l}200 \text { MW Molokai to } \\
\text { Koolau, } 200 \text { MW Lanai to } \\
\text { Iwilei, } 200 \text { MW Lanai to } \\
\text { Molokai }\end{array}$} & \multirow[t]{2}{*}{$\begin{array}{l}400 \mathrm{MW} \\
\text { Molokai to } \\
\text { Iwilei }\end{array}$} & \multirow{2}{*}{$\begin{array}{l}200 \mathrm{MW} \\
\text { Molokai to } \\
\text { Koolau, } \\
200 \mathrm{MW} \\
\text { Lanai to } \\
\text { Koolau }\end{array}$} & \multirow{2}{*}{$\begin{array}{l}200 \mathrm{MW} \\
\text { Molokai to } \\
\text { Iwilei, } \\
200 \mathrm{MW} \\
\text { Lanai to } \\
\text { Iwilei }\end{array}$} \\
\hline & & & (a) & (b) & & & \\
\hline Stations (\$M) & $\$ 234$ & $\$ 288$ & $\$ 414$ & $\$ 342$ & $\$ 234$ & $\$ 288$ & $\$ 288$ \\
\hline Cables (\$M) & $\$ 154$ & $\$ 180$ & $\$ 367$ & $\$ 424$ & $\$ 221$ & $\$ 216$ & $\$ 245$ \\
\hline $\begin{array}{l}\text { Total Stage } 1 \\
\text { Price (\$M) }\end{array}$ & $\$ 388$ & $\$ 468$ & $\$ 781$ & $\$ 766$ & $\$ 455$ & $\$ 504$ & $\$ 533$ \\
\hline
\end{tabular}

The distribution of projected costs are shown in Table 10, including Option B1-2-the option chosen in this study. The option we chose was neither the highest- nor the lowest-cost option, but rather the second highest cost in the distribution, which we felt was representative of a cable system cost. Furthermore, we added a factor of $10 \%$ to the estimate as a conservative element and to represent soft costs that were not included in the Electranix numbers.

\section{Oahu Grid Improvements}

The costs of improvements required on Oahu, Lanai, and/or Molokai to connect wind power to the system depend on the selection of landing site(s) and technologies and configurations chosen by the project. While HECO has conducted technical and costbased studies of the potential landing sites on Oahu, the specifics of that information are considered business-sensitive as it contemplates a procurement process that could be biased if details were released prematurely. For this reason, the detailed information remains confidential.

In response to this necessary confidentiality, the methodology used to represent these costs is not explained in detail here. Using a range of confidential inputs provided to NREL by HECO, we used a placeholder for the capital costs required on Oahu by HECO as $\$ 205,000,000$.

\section{Project Residual Value}

Residual value, or salvage value, is a term used in financial analysis for the remaining value of a project or asset at the end of an analysis period. The major components of the Big Wind project are expected to have productive life well beyond 20 years. In the model, we used a residual value of $30 \%$ of the original project cost. This is essentially a plug number used to begin the analysis and subject to sensitivity testing. 


\section{Revenue}

The concept of revenue in this analysis is the revenue the project receives or requires to be economic. Alternatively, this revenue is provided by the purchaser of the energy and transmission services, and is viewed as a cost. As described earlier, we gathered the cost and performance inputs necessary for the financial model and solved for the revenue required to meet a substantially positive NPV.

In our approach, cost information for all three major elements of the project are aggregated in the model, so the revenue line is actually representing the collective revenue demanded by Big Wind given the project costs, opportunity cost of capital, and other inputs. In this way, we are running the analysis from the perspective of the project, i.e. what might the market require in terms of revenue to pursue and complete the project? We are solving for revenue given what we know, not specifying a revenue level justified in some other way.

There may or may not be a revenue stream with the characteristics we are modeling; it depends on the overall project organization and structure, which is not known and is not included in the scope of this work. Nevertheless, the design of our approach is very useful for two reasons:

1. The revenue line for the project is inversely considered a "cost" to the system for the power generated. As a cost, it is useful to compare to existing or alternative costs of renewable generation that may or may not include significant transmission components.

2. It allows us to compare the costs of generation contemplated by the project against various costs of generation by HECO's system given various costs of petroleum or bio-fuels.

\section{Delivered Energy}

In our assumptions, revenue occurs when renewable energy is delivered and accepted by the Oahu grid. Developing the quantity of delivered energy after conversion and system losses, including curtailment, is therefore a key component of determining project revenue and overall economic performance. Wind resource, system line and conversion losses, and potential curtailment of wind farm production as necessary for utility integration must be accounted for. We relied on the work of the OWITS studies, the TRC, and the experts involved in conducting those studies to arrive at the following losses and adjustments to delivered energy numbers:

1. Conversion and line losses of 3.9\% are assumed in the model for the high-voltage direct current (HVDC) cable system.

2. Downtime for equipment maintenance/availability for the HVDC cable system and associated converter stations included as a $1.1 \%$ reduction. 
3. After taking the discounts above, and based on the wind resource capacity factor determined by the TRC in the study area, the capacity factor for the wind farm included in our model is $47.2 \%$.

4. Annual curtailment for the wind farm is modeled in our calculations as $90,000 \mathrm{MWh}$ (6\% of total production capacity at $47.2 \%$ capacity factor).

\section{Capacity Factor}

Given the numbers that were available from draft OWITS reports at the time of this analysis (April 2010), including confidential data sources, and the discussion of losses applied provided per the paragraph above, we used a capacity factor for delivered energy to the Oahu grid of $42.29 \%$.

\section{Revenue Source(s)}

During the analysis, we considered multiple potential sources of revenue per megawatt hour delivered, including trying to account for potential sources of value such as carbon credits and/or renewable energy credits, neither of which exist in the Hawaii market today, but may in the future. Ultimately, based on the analysis approach used and the goals of the analysis, the source of revenue is not particularly relevant-we are seeking to characterize the likely amount of total revenue, or cost per megawatt hour that the project requires.

\section{Operating Costs/Expenses}

Operating costs of the entire system were represented in terms of operations and maintenance $(\mathrm{O} \& \mathrm{M})$ expenses likely incurred by each of the three major project elements: wind farms, cable system(s), and grid operations on Oahu. The O\&M costs were represented per megawatt hour delivered for the wind farms, as $1 \%$ of installed costs for the cable system(s), and on megawatt hours delivered for grid impacts.

\section{Cash Flows}

The model uses the inputs described above - capital expenditures, residual value, and delivered energy and revenue/megawatt hour delivered, less operating costs, to derive annual project cash flows across the life of the project.

\section{Incentives and Taxes}

As a simplifying assumption, we ignored government incentives or tax implications in this model, as the two are very closely linked, based on the existing tax-based incentive policies currently available to a project of this type. This was done to simplify the model, but also to concentrate on the fundamental economics involved vs. the financing schemes available, which is consistent with industry best practices for early-stage project analysis. 


\section{Leverage}

The analysis assumes no debt, as described more in the following paragraph(s).

\section{Opportunity Cost of Capital}

A key part of the theory and practice surrounding the use of NPV analysis revolves around this concept and the resulting input. It can be called, at times, discount rate, interest rate, hurdle rate, internal rate of return, cost of capital, and opportunity cost of capital.

The concept is to use a cost of capital, which is established by the capital markets as the return required by equity investors (in the public equity markets), to invest in securities that carry the same risk characteristics of the project being considered. It is an opportunity cost because, for example, the risk is the same if an investor chooses to invest in Big Wind over another security, the investor is forgoing the return that could have been garnered by investing in the other security, so there is a lost opportunity by investing in the project.

The opportunity cost is not meant to, and does not attempt to, approximate the actual cost of financing the project. In fact, when leverage is introduced, it is likely that the weighted average cost of capital for the entire project is lower than the opportunity cost of capital. In fact, it should be if it's a well-designed financing strategy. The reason is that financing (debt) introduces different elements of financial risks and mitigation strategies, such as secured investment structures enhanced by either captive revenue streams or third-party balance sheet support. These tend to obscure the underlying risks of the project one way or the other, distorting the analysis and potentially influencing bad investment decisions.

In the case of this Big Wind analysis, we used a cost of capital for the project of $12 \%$. This came from recent presentations by market participants as well as general knowledge and experience in the market. This input is subject to sensitivity analysis and will be tested through a range of values; $12 \%$ was judged as a reasonable starting point given the early-stage nature of the project and the general characteristics and risk profile of the undertaking.

Inflation is factored into the revenue and operating costs at an annual rate of $2.25 \%$. This is a value used as a baseline for inflation and will be subject to sensitivity analysis across a range of values to understand the impact of inflation on the project economics. 


\section{FOOTNOTES}

1 State of Hawaii. Department of Business Economic Development and Tourism. Energy Agreement Among The State of Hawaii, Division of Consumer Advocacy of The Department Of Commerce And Consumer Affairs, and The Hawaiian Electric Companies. http://hawaii.gov/dbedt/info/energy/ agreement/signed2008oct20.pdf.

2 Hawaii State Legislature Website. Hawaii Revised Statutes. www.capitol.hawaii.gov/hrscurrent/ Vol05_Ch0261-0319/HRS0269/HRS_0269-0091.htm.

3 Oahu Wind Integration Study. University of Hawaii. Hawaii Natural Energy Institute. School of Ocean and Earth Science and Technology. February 2011. www.hnei.hawaii.edu/PDFs/Oahu_Wind_ Integration_Study.pdf.

Corbus, D.; Schuerger, M.; Roose, L. et al. November 2010. Oahu Wind Integration and Transmission Study: Summary Report. NREL/TP-5500-48632. Golden, CO: National Renewable Energy Laboratory. www.nrel.gov/docs/fy110sti/48632.pdf.

Woodford, D. Oahu Wind Integration and Transmission Study (OWITS). February 2011. NREL/ SR-5500-50411. Golden, CO: National Renewable Energy Laboratory. www.nrel.gov/docs/fy11osti/ 50411.pdf.

Woodford, D. Phase 2 Report: Oahu Wind Integration and Transmission Study (OWITS). Hawaiian Islands Transmission Interconnection Project. February 2011. NREL/SR-5500-50414. Golden, CO: National Renewable Energy Laboratory. www.nrel.gov/docs/fy110sti/50414.pdf.

4 Draft Document. Hawaii Clean Energy Initiative Scenario Analysis: Quantitative Estimates Used to Facilitate Working Group Discussions. (2008). Prepared for DOE. March 31, 2011.

5 Woodford, D. Oahu Wind Integration and Transmission Study (OWITS). National Renewable Energy Laboratory. Subcontract Report NREL/SR-5500-50411. February 2011. www.nrel.gov/docs/fy110sti/ 50411.pdf

6 Gilman, P, Blair, N, Mehos, M, Christensen, C, Janzou, S, Cameron, C. Solar Advisor Model User Guide for Version 2.0. National Renewable Energy Laboratory. Technical Report NREL/TP-670-43704. August 2008

7 SAM. National Renewable Energy Laboratory. www.nrel.gov/analysis/sam/support.html.

8 We did not attempt to estimate the capital cost associated with the growing and refining of biofuels in-state, as it is not clear whether biofuels would be imported under this scenario, or whether the cost of production of in-state biofuels would differ significantly from international prices.

9 Year one revenue was calculated in the analysis for Big Wind. The same revenue is being used for all solar scenarios to allow for direct comparison of NPV's for each technology option.

10 Year one revenue was calculated in the analysis for Big Wind. The same revenue is being used for all solar scenarios to allow for direct comparison of NPV's for each technology option.

11 Year one revenue was calculated in the analysis for Big Wind. The same revenue is being used for all solar scenarios to allow for direct comparison of NPV's for each technology option.

12 Wiser, R, Bolinger M. 2009 Wind Technologies Market Report. U.S. Department of Energy. DOE/ GO-102010-3107. August 2010. www1.eere.energy.gov/windandhydro/pdfs/2009_wind_ technologies_market_report.pdf

13 National Biodiesel Board. "Fuel Fact Sheets." Biodiesel Production Estimates CY2005—current. www. biodiesel.org/pdf_files/fuelfactsheets/Production_Graph_Slide.pdf. 


\section{National Renewable Energy Laboratory}

15013 Denver West Parkway, Golden, CO 80401

303-275-3000 • www.nrel.gov

NREL is a national laboratory of the U.S. Department of Energy

Office of Energy Efficiency and Renewable Energy

Operated by the Alliance for Sustainable Energy, LLC.

NREL/TP-7A40-54248 • March 2012

Printed with a renewable-source ink on paper containing at least $50 \%$ wastepaper, including $10 \%$ post consumer waste. 